\section{DE DE GRUYTER} OPEN
Journal of Intercultural Management

Vol. 5, No. 2, June 2013, pp. 31-62

DOI 10.2478/joim-2013-0009

Maciej Popławski

General Tadeusz Kościuszko Military Academy of Land Forces in Wrocław

\title{
Impact of foreign direct investment on lower silesia's economic development
}

\begin{abstract}
The paper presents research results concerning the impact of foreign direct investments on the economic development of Lower Silesia in the years 1999-2011. The first year analysed is 1999 - the year in which the new administrative division was introduced into Poland, where the number of provinces was reduced from 49 to 16, with 314 districts and 65 cities being given district rights (including communes which also accomplish the tasks of the district). ${ }^{1}$

The research takes into account the most important macroeconomic indicators presenting the region's development, such as the GDP and investment and employment levels. These indices are based on data from the Statistical Office in Wrocław and the Central Statistical Office of Poland (GUS). Data on companies and entities with foreign capital have been correlated with the above-mentioned indicators to evaluate the foreign investment influence on the region's economy.
\end{abstract}

Key words: foreign direct investment, regional development, entities with foreign capital, commercial companies, macroeconomic factors

\section{Introduction}

The transformations, initiated in Poland by political changes of 1989, resulted in opening the Polish economy to Western European countries [See more: Popławski 2012, pp. 37-38]. Due to its political, social and economic advantages as well as its geoFigureic location, Poland's economic development was permanently determined by the inflow of foreign capital [Wieczorkiewicz 2002, p. 8]. Thanks to favourable conditions for the inflow of foreign capital at the beginning of the transformation, foreign investors rapidly became more

1 The number of district towns in Poland reaches 335, including 44 towns which are at the same time seats of the district and towns with district rights. 
competitive than local enterprises. Many global corporations included Poland in their net development strategies and chose the best moment for implementing these strategies [Rocznik PAIiIZ 2003, 2004 pp. 49-54]. What encouraged companies to invest in Poland in the first years of the transformation was low labour costs [Compare: Karaszewski 2007, p. 234]. Nowadays investors perceive labour costs as dynamically increasing, and therefore pay more and more attention to skilled staff. Most perceive Poland's human resources as well qualified [Compare: Frąckowiak 2001, p. 95]. Other beneficial factors include lower tax burdens as compared with those found in other EU Member States and lower real property prices [Compare: Karaszewski 2007, p. 235], both of which play a significant role among greenfield companies [Karaszewski 2007, p. 237].

\section{Materials and methods}

The goal of the study is to measure the impact of foreign direct investments on the economic development of Lower Silesia in the years 1999-2011 on the base of GUS data.

In the first part of the research, an analysis was carried out concerning the share of companies with foreign capital within the total number of commercial companies. Next, quantitative changes in the inflow of companies with foreign capital were compared to quantitative changes in the inflow of commercial companies. It was assumed that with the previous year had 100 such companies. Then, those foreign companies investing their capital in Polish enterprises was defined, and after that, the dynamics of changes in those Polish enterprises boosted with foreign capital were compared with the dynamics of primary capital changes in all enterprises, assuming again that the previous year had 100. Following that step, quantitative changes in the foreign capital, investments and employment rates of those entities with foreign capital were compared with the dynamics of changes in the regional GDP. Maps present the location of companies with foreign capital in Lower Silesia within a division, into subregions and districts for the years 2000, 2005 and 2010. Further on in the research, the number of people employed in entities with foreign capital were compared with the total number of people working in Lower Silesia, and a comparative analysis was carried out to determine the quantitative changes regarding people employed in entities with foreign capital as compared with the quantitative changes among all people employed, by assuming the previous year as having had 100 such enterprises. In the final part of the research, investment expenditure incurred by entities with foreign capital was compared with the total investment expenditure incurred by enterprises in Lower Silesia, and the dynamics of the process were analysed by assuming that there were 100 enterprises the previous year. 
Numerous barriers were encountered while collecting statistical materials necessary to carry out the above-mentioned analyses, which resulted mainly from difficulty in comparing data or simply the lack of data itself. Some of the obstacles stemmed from the fact that GUS does not have data on the amount of the primary capital, number of investments, and number of people employed in commercial companies, including companies participating with foreign capital; the information available to GUS includes only data related to all enterprises and to entities with foreign capital. In view of the above, a comparative analysis was made to define the impact of foreign investments on the economic development of a region, and research was carried out, covering the above-mentioned indicators, regarding business entities participating with foreign capital and all enterprises. Another obstacle was GUS's incomplete statistical data relating to business entities with foreign capital. For example, according to the REGON register maintained by GUS, in 2010 the number of companies with foreign capital reached 6521 in Lower Silesia, while according to data available on the portal of the local data bank (www.stat.gov.pl) and in the paper "Business Activity Conducted by Entities with Foreign Capital in 2010", this number reached only 2274. This incongruity stems from the fact that GUS gathers data from annual reports prepared by the entities. What was used to define the role of foreign capital in the establishment of enterprises and location of foreign investments was scrambled with data on companies, namely, on those which contributed the most significantly to regional development.

\section{Conditions of the inflow of foreign capital}

Good conditions for foreign investment inflow are created, most of all, by a favourable policy pursued by Poland. Since the very beginning of the 1990s Poland's national policy has focussed on [Sadowski 1999, pp.40-41] actively promoting investments aimed at development. The following are examples of such promotions: Poland has improved the country's image as an attractive location for investments and provided investors with necessary information (e.g. through such state organisations as the Polish Information and Foreign Investment Agency); given direct support to investors (subsidies for the investment); established contacts (through conferences, fairs); created conditions for transferring and using technology such as formulating a policy aimed at attracting high technology, creating attractive opportunities for technology transfers (inter alia by means of supporting such domestic research institutions as technology parks); financed scientific research and supported innovativeness; provided opportunities to commercialise the results of scientific research; enabled local labour to gain proper qualifications by creating conditions for improving qualifications; encouraged investors to create staff education centres and qualification improvement schemes, good 
technical and social infrastructure; and supported connections with the global market through trade and flow of services and capital [See more: Popławski 2012, pp. 38-41].

Apart from creatin proper capital inflow conditions, tasks to be accomplished by the state also include removing the following existing obstacles and barriers: [Dobrodziej 1999, p. 136; Sadowski 1999, pp.58, 59; Olesiński 1998, p. 84] instability in the tax system and tax rates; lack of transparency in provisions related to privatisation and the unsatisfactory offer of enterprises for sale; too frequently amended legal provisions; an unstable customs policy; low profitability in taking bank loans; too high financial burdens for enterprises; bureaucratisation of administrative decisions (complex bank procedures for granting loans, difficulties for foreigners in purchasing land and real property); an underdeveloped services sector; and an inept transport infrastructure requiring modernisation.

Generally speaking, Polish legislation may be perceived as rather liberal when it comes to attracting foreign capital to Poland. Foreign investors enjoy both freedom of economic activity and tax relief to the same extent as domestic investors. Moreover, they may easily transfer profits abroad, and in the event of bankruptcy they may transfer their capital abroad, while in cases of expropriation they are entitled to indemnity.

Adverse consequences of the political transformation (inter alia a fall in production, increase in the unemployment rate, increase in unused production resources) brought about considerable disturbances in the economic structure of many Polish regions. Local authorities did not manage to solve these problems on their own. What was necessary was the state aid, which was embodied, for example, by the Special Economic Zones Act (SEZ) of 20 October 1994. Under SEZ, Special Economic Zones were established [Cieślik 2005, p. 95] to activate a region's economic development by involving external strategic investors. The basic method for attracting capital and technology is have favourable tax policies for defined fields of business activity, in particular for sectors that guarantee optimal conditions for local development. Since 2007 the 14 SEZ areas have increased from eight to more than 13 thousand hectares. Investment value in the Zones has exceeded 31 billion PLN and the number of employees has reached approximately 100 000. The Zones were established for 20 years, which includes, in that time period, complete exemption from income taxes for 10 years and another 10 years during which the entrepreneur has to pay only $50 \%$ of the amount due to the State Treasury. Industrial and technology parks are excepted, as their period of operation was shortened to 12 years and the period of complete exemption from taxation is six years. SEZ follows much easier procedures for obtaining building permits (decisions on issuance 
of a building permit are issued by the zone administrator rather than the head of the regional office) and quicker procedures related to the purchase of real property by foreigners. There are four Zones in Lower Silesia: Kamiennogórska SEZ for Small Business, Legnica SEZ, Tarnobrzeg SEZ Euro-Park Wisłosan and Wałbrzych SEZ Invest-Park.

\section{Analysing the influence of direct foreign investments on Lower Silesia's economic development in the years 1999-2011}

Lower Silesia is perceived as the second most attractive region for foreign investors (on the same footing with Masovia) [Compare: Nowicki 2011]. The policy pursued by local authorities is aimed at facilitating entry by foreign investors into the market. Apart from acquiring shares in state-owned enterprises, the largest global concerns also decided to construct their own factories, which is evidence of the investors' considerable confidence and conviction that the region is not only an attractive place for building factories but also abounds with highly-skilled staff [Urząd Marszałkowski Województwa Dolnośląskiego datebase, [Online], Available: http://www.umwd.dolnyslask.pl/ gospodarka/inwestycje-zagraniczne/najwiksiinwestorzy/ [12.10.2012].

The largest investors in Lower Silesia include (data divided according to the investor's country of origin) [Urząd Marszałkowski Województwa Dolnośląskiego datebase, [Online], Available: http://www.umwd.dolnyslask.pl/ gospodarka/inwestycje-zagraniczne/najwiksiinwestorzy/ [12.10.2012]:

- British capital: Cadbury Schweppes, Cussons Group Ltd, British Vita, BOC, Tesco, Shell, BP, GKN;

- American capital: Whirlpool-Polar S.A., Wabco, PepsiCo, The Gates Corporation, CC HBC, Cargill, McDonald's, American Retail System, Armstrong, Gerber Company, General Electric International, Tricon.;

- German capital: Deutsche Bank, BTR Automotive, SCA Hygiene Products Holding GmbH, Siemens, Quarzwerke $\mathrm{GmbH}$, Roeben Tonbaustoffe, Bayerische Hypo und Vereinsbank AG, Metro, firma wydawnicza Phoeniks, Mercedes (S. Zasada), Bosch, Alstom, Flessner, Volkswagen, Makro, Selgros, OBI, Aral, Schoeller, Schneider, DEA, Real, Automotive, Petri, Mini Mal, Gossmann Polska;

- Swedish-Swiss and Swedish capital: ABB, Volvo, Electrolux, Trelleborg Automotive, IKEA, DeLaval;

- French capital: Faurecia, Credit Agricole-Lukas Bank, Castorama, Carrefour, Geant, E'Leclerc, Brandt, Alstom, Lucas Bank;

- Dutch capital: SCA Molnlycke, Boart Longyear, 3M;

- Canadian capital: McCain, Northen Telecom, Royal Europa, Bombardier Transportation Polska;

- Japanese capital: Takata Petri, Toyota; 
- Spanish capital: Fagor;

- Korean capital: LG Electronics.

The following sectors are the most popular [Urząd Marszałkowski Województwa Dolnośląskiego datebase, [Online], Available: http://www. umwd.dolnyslask.pl/gospodarka/inwestycje-zagraniczne/najwiksiinwestorzy/ [12.10.2012]: banking and insurance, automotive industry, food production, machine-building, chemical and non-metal industries, electronic industry, fuel stations, supermarket and hypermarket chains, hotels and restaurants.

\section{Companies with foreign capital vs all commercial companies}

A vast majority of foreign enterprises operating in Poland have established capital companies (limited liability companies and joint stock companies) and conduct economic activities using domestic capital. It is undoubtedly evidence of the investors' serious intentions, whose objectives include development and investments.

Since 1999 the number of companies using foreign capital has been systematically increasing in Lower Silesia: from 4066 in 1999 to 6658 in 2011; however, it did not increase as much as as the number of all commercial companies, whose number has risen almost by 100\%, from 12,056 in 1999 to 25,994 in 2011 (Tables $1 \mathrm{a}$ and $1 \mathrm{~b})$. Thus, a conclusion may be drawn that in the entire period under analysis, domestic investors were more and more inclined to commence activities in Lower Silesia, which is perfectly illustrated on Figure 1.

Table 1a. Companies with foreign capital vs all commercial companies in Lower

Silesia in the years 1999-2011

\begin{tabular}{|l|l|l|l|l|l|l|l|l|l|l|l|l|l|}
\hline & 1999 & 2000 & 2001 & 2002 & 2003 & 2004 & 2005 & 2006 & 2007 & 2008 & 2009 & 2010 & 2011 \\
\hline $\begin{array}{l}\text { Total number } \\
\text { of commercial } \\
\text { companies }\end{array}$ & 12056 & 13211 & 14674 & 16157 & 17104 & 18076 & 18966 & 20021 & 21314 & 22060 & 23188 & 24782 & 25994 \\
\hline $\begin{array}{l}\text { Companies } \\
\text { with foreign } \\
\text { capital }\end{array}$ & 4066 & 4379 & 4571 & 4689 & 4834 & 5095 & 5375 & 5681 & 6000 & 6178 & 6346 & 6521 & 6658 \\
\hline $\begin{array}{l}\text { Share of } \\
\text { companies } \\
\text { with foreign } \\
\text { capital in the } \\
\text { total number } \\
\text { of commercial } \\
\text { companies } \\
\text { (\%) }\end{array}$ & 33.7 & 33.1 & 28.3 & 29.0 & 28.3 & 28.2 & 28.3 & 28.4 & 28.1 & 28.0 & 27.4 & 26.3 & 25.6 \\
\hline
\end{tabular}

Source: Own study on the basis of Statistical Yearbooks of Lower Silesia 1999-2010, Statistical Office, Wrocław, 2000-2011 and the portal of the local data bank available at www.stat.gov.pl 
Another conclusion drawn from Table 2a is that the percentage share of companies with foreign capital in the total number of commercial companies was gradually reduced from $33.7 \%$ in the first year to $25.6 \%$ in 2011, which confirms that the number of all commercial companies increased more rapidly than the number of companies using foreign capital, in particular in the most recent years (Table 1b, Figure 2). However, this does not mean that foreign investors were less interested in the region, but that they were more willing to invest in large companies, which was proved in the further part of the analysis (see point 2.2).

Figure 1. Companies with foreign capital vs all commercial companies in Lower Silesia in the years 1999-2011

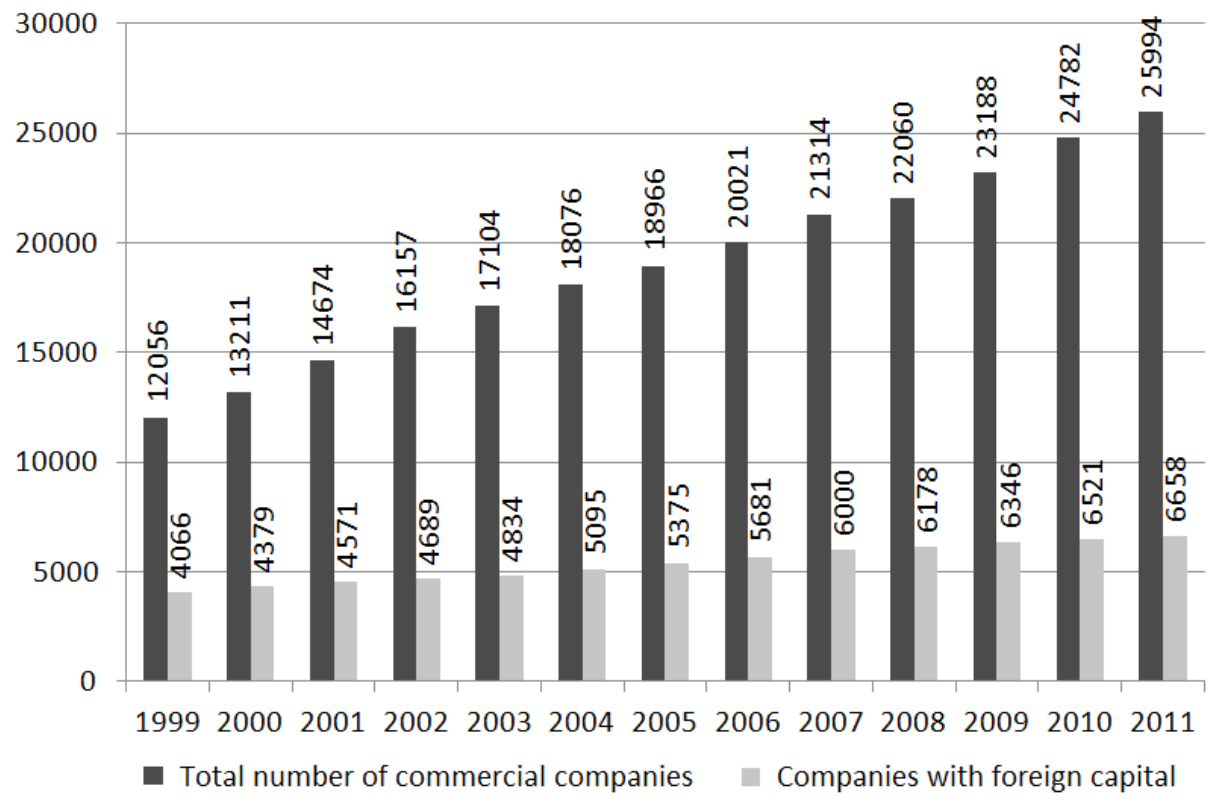

Source: Own study on the basis of Statistical Yearbooks of Lower Silesia 1999-2010, Statistical Office, Wrocław, 2000-2011 and the portal of the local data bank available at www.stat.gov.pl 
Table 1b. Dynamics of quantitative changes in the inflow of companies with foreign capital vs dynamics of quantitative changes in the inflow of all commercial companies in Lower Silesia in the years 1999-2011 (previous year $=100)$

\begin{tabular}{|l|l|l|l|l|l|l|l|l|l|l|l|l|l|}
\hline & 1999 & 2000 & 2001 & 2002 & 2003 & 2004 & 2005 & 2006 & 2007 & 2008 & 2009 & 2010 & 2011 \\
\hline $\begin{array}{l}\text { Total number } \\
\text { of commercial } \\
\text { companies }\end{array}$ & 109.43 & 109.58 & 111.97 & 110.11 & 105.86 & 105.68 & 104.92 & 105.56 & 106.46 & 103.50 & 105.11 & 106.86 & 104.89 \\
\hline $\begin{array}{l}\text { Companies } \\
\text { with foreign } \\
\text { capital }\end{array}$ & 112.76 & 108.23 & 104.64 & 103.47 & 103.42 & 105.17 & 105.50 & 106.34 & 106.51 & 103.78 & 103.07 & 103.79 & 102.10 \\
\hline
\end{tabular}

Source: Own study on the basis of Statistical Yearbooks of Lower Silesia 1999-2010, Statistical Office, Wrocław, 2000-2011 and the portal of the local data bank available at www.stat.gov.pl

Despite the noticeable convergence of both groups analysed, Figure 2 also indicates that the increase in both categories of companies under analysis was weakened.

Figure 2. Dynamics of quantitative changes in the inflow of companies with foreign capital vs dynamics of quantitative changes in the inflow of all commercial companies in Lower Silesia in the years 1999-2011 (previous year $=100)$

112

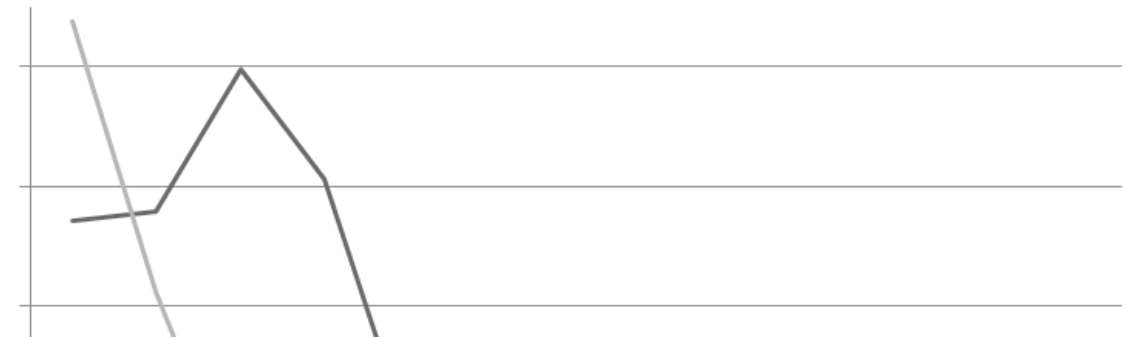

108

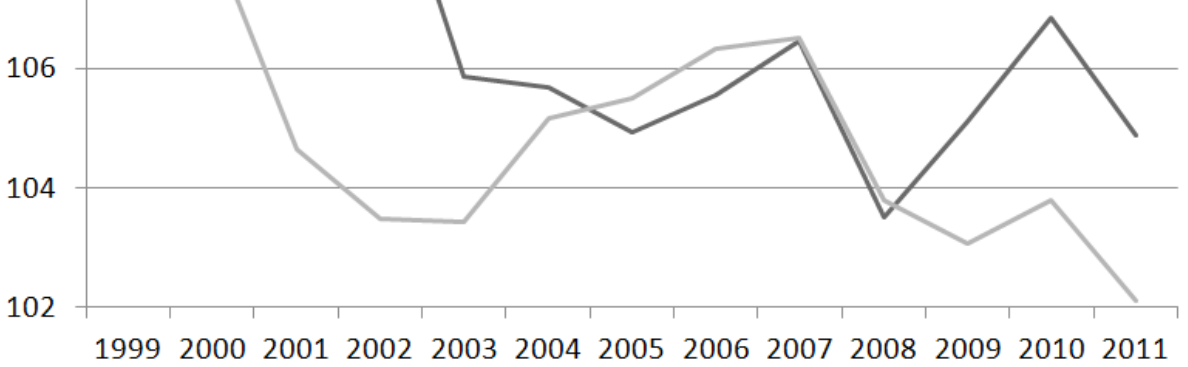

1999200020012002200320042005200620072008200920102011

_ Total number of commercial companies Companies with foreign capital

Source: Own study on the basis of Statistical Yearbooks of Lower Silesia 1999-2010, Statistical Office, Wrocław, 2000-2011 and the portal of the local data bank available at www.stat.gov.pl 


\section{Foreign capital of entities with foreign capital vs total primary capital of enterprises}

When analysing the share of foreign capital in the total primary capital of enterprises a conclusion may be drawn that despite a reduced share of companies using foreign capital in the total number of commercial companies, the entities with foreign capital recorded an increase in their capital by more than $100 \%$ : from a little more than $18 \%$ at the beginning of the period analysed to almost $41 \%$ in 2011 (see Table 2a). What is worth mentioning here is that the total value of the primary capital in enterprises in Lower Silesia was doubled, while the value of the foreign capital in entities with foreign capital was tripled (see Table 2a, Figure 3). It is undoubtedly the evidence that foreign investors are interested in large investments, which confirms again that they are seriously interested in the region.

Table 2a. Foreign capital of entities with foreign capital vs total primary capital of enterprises in Lower Silesia in the years 1999-2010 in million PLN

\begin{tabular}{|c|c|c|c|c|c|c|c|c|c|c|c|c|}
\hline & 1999 & 2000 & 2001 & 2002 & 2003 & 2004 & 2005 & 2006 & 2007 & 2008 & 2009 & 2010 \\
\hline $\begin{array}{l}\text { Total } \\
\text { primary } \\
\text { capital of } \\
\text { enterprises }\end{array}$ & no data & $16727 . \varepsilon$ & $8 \mid 18339.4$ & 20181.1 & 21687.3 & \begin{tabular}{l|l}
3 & 24617.9
\end{tabular} & 28794.7 & 31444.9 & 34240.3 & 34006.4 & 35254.6 & 35533.9 \\
\hline $\begin{array}{l}\text { Foreign } \\
\text { capital of } \\
\text { entities } \\
\text { with foreign } \\
\text { capital }\end{array}$ & 3380.8 & 3124.1 & 3744.1 & 4333.6 & 5189.5 & 6834.6 & 9575.0 & 11384.2 & 12727.5 & 13410.3 & 14364.2 & 14509.9 \\
\hline \begin{tabular}{|l|} 
Share of \\
foreign \\
capital of \\
entities \\
with foreign \\
capital \\
in the total \\
primary \\
capital of \\
enterprises \\
(\%)
\end{tabular} & & 18.7 & 20.4 & 21.5 & 23.9 & 27.8 & 33.2 & 36.2 & 37.2 & 39.4 & 40.7 & 40.8 \\
\hline
\end{tabular}

Source: Own study on the basis of Statistical Yearbooks of Lower Silesia 1999-2010, Statistical Office, Wrocław, 2000-2011 and the portal of the local data bank available at www.stat.gov.pl 
Figure 3. Foreign capital of entities with foreign capital vs total primary capital of enterprises in Lower Silesia in the years 1999-2011 in million PLN

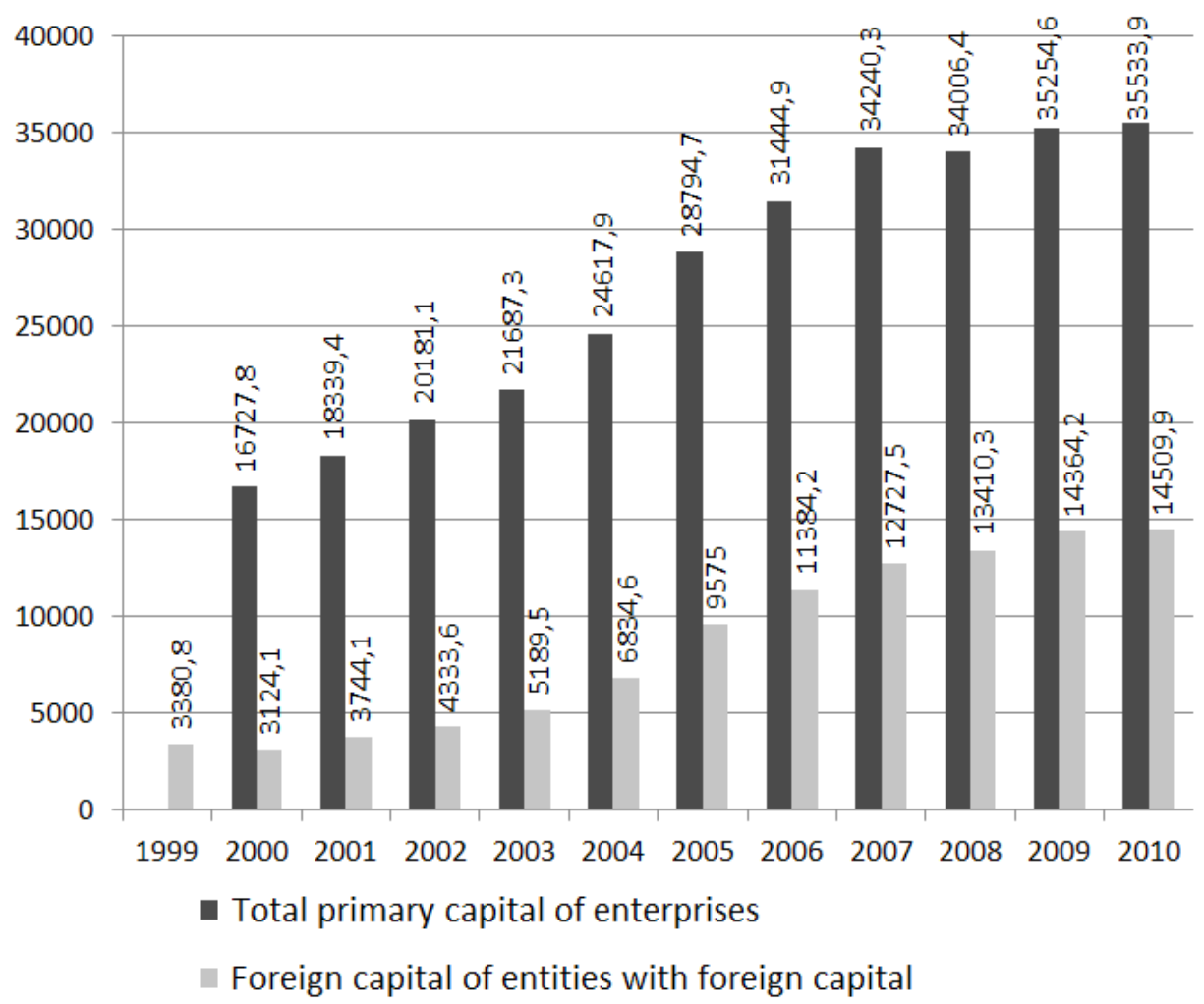

Source: Own study on the basis of Statistical Yearbooks of Lower Silesia 1999-2010, Statistical Office, Wrocław, 2000-2011 and the portal of the local data bank available at www.stat.gov.pl

The dynamics of this phenomenon are presented in Table $2 \mathrm{~b}$ and Figure 4 . As it stems from this Table and Figure, by 2005 the primary capital in both categories analysed was greatly increased, whereas after 2005 a gradual weakening was recorded, which persisted till the end of the period under analysis. 
Table 2b. Dynamics of quantitative changes in the foreign capital of entities with foreign capital vs dynamics of quantitative changes in the total primary capital of commercial companies in Lower Silesia in the years 1999-2011 (previous year $=100$ )

\begin{tabular}{|l|l|l|l|l|l|l|l|l|l|l|l|l|}
\hline & 1999 & 2000 & 2001 & 2002 & 2003 & 2004 & 2005 & 2006 & 2007 & 2008 & 2009 & 2010 \\
\hline $\begin{array}{l}\text { Total primary capital } \\
\text { of enterprises }\end{array}$ & no data & no data & 126.32 & 71.96 & 87.52 & 123.24 & 114.45 & 128.80 & 115.45 & 102.86 & 90.53 & 93.65 \\
\hline $\begin{array}{l}\text { Foreign capital of } \\
\text { entities with foreign } \\
\text { capital }\end{array}$ & - & 108.32 & 113.85 & 115.74 & 119.75 & 131.70 & 140.10 & 118.90 & 11.80 & 105.36 & 107.11 & 101.01 \\
\hline
\end{tabular}

Source: Own study on the basis of Statistical Yearbooks of Lower Silesia 1999-2010, Statistical Office, Wrocław, 2000-2011 and the portal of the local data bank available at www.stat.gov.pl

Figure 4. Dynamics of quantitative changes in the foreign capital of entities with foreign capital vs dynamics of quantitative changes in the total primary capital of commercial companies in Lower Silesia in the years 1999-2011 (previous year $=100$ )

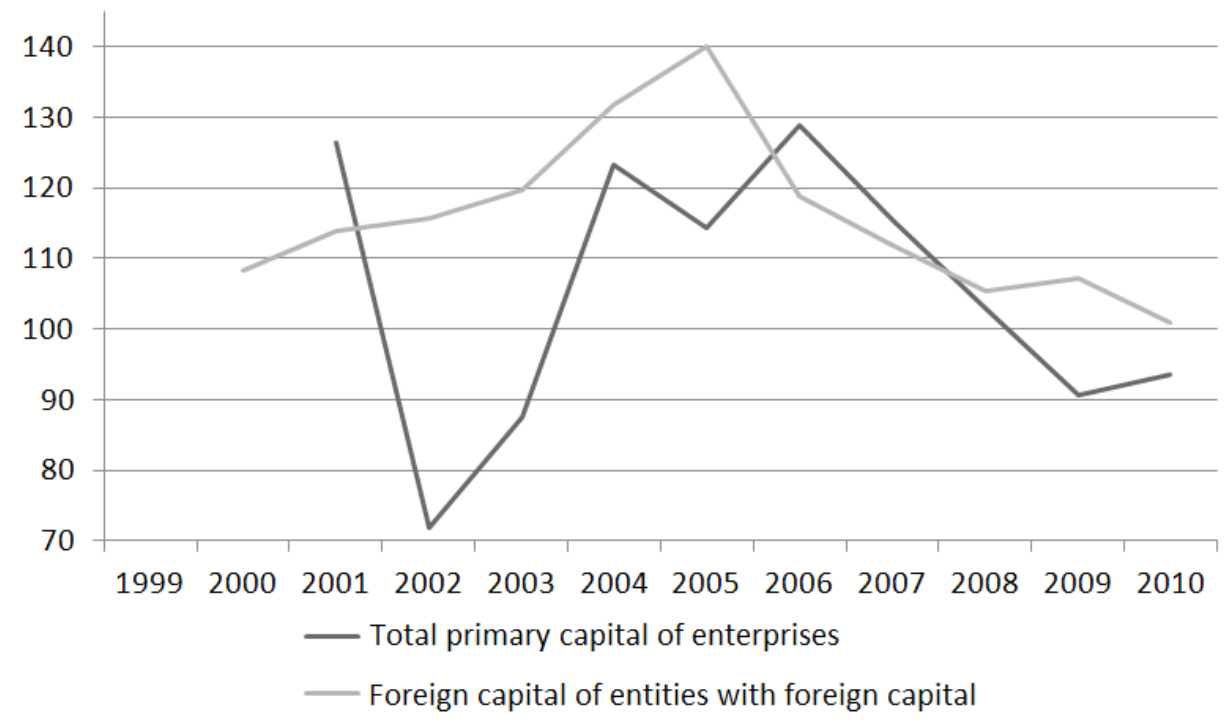

Source: Own study on the basis of Statistical Yearbooks of Lower Silesia 1999-2010, Statistical Office, Wrocław, 2000-2011 and the portal of the local data bank available at www.stat.gov.pl

As the data shows, increases $\mathrm{n}$ the primary capital of both categories were subject to considerable fluctuations: up to 50 percentage points for the total number of enterprises, whereas in the case of companies with foreign capital - approximately. $40 \%$. What can also be observed here is that both types of business activity convergence. 


\section{Foreign capital of entities with foreign capital vs GDP}

The most important effect of direct foreign investments on the region's economic development is their impact on GDP. Apart from an increase in GDP through production of new goods, direct foreign investments also result in transferring state-of-the-art technologies, know-how, techniques of management and use of modern marketing, which indirectly increases their value [From the parliamentary question of Speaker of the Sejm Grzegorz Schetyna, 13.04.2011, pp.1-2].

As Table 3 and Figure 5 show, the insignificant fluctuations in GDP were accompanied from 2007 by fluctuations in foreign capital in the in entities using foreign capital. In the remaining period no particular connection was observed between the two categories; in fact, divergence was observed. Thus, a conclusion may be drawn that entities using foreign capital created only an insignificant impact on GDP through 2007, and it is only after 2007 that a certain convergence may be observed.

Table 3. Dynamics of quantitative changes in the foreign capital of entities with foreign capital vs dynamics of changes in GDP in Lower Silesia in the years 1999-2011

\begin{tabular}{|l|l|l|l|l|l|l|l|l|l|l|l|l|}
\hline & 1999 & 2000 & 2001 & 2002 & 2003 & 2004 & 2005 & 2006 & 2007 & 2008 & 2009 & 2010 \\
\hline GDP & 113.57 & 110.52 & 102.08 & 105.5 & 103.27 & 108.85 & 107.83 & 111.48 & 112.7 & 107.1 & 106.80 & $\begin{array}{l}\text { no } \\
\text { data }\end{array}$ \\
\hline $\begin{array}{l}\text { Foreign } \\
\text { capital } \\
\text { of } \\
\text { entities } \\
\text { with } \\
\text { foreign } \\
\text { capital }\end{array}$ & - & 108.32 & 113.85 & 115.74 & 119.75 & 131.70 & 140.10 & 118.90 & 111.80 & 105.36 & 107.11 & 101.01 \\
\hline
\end{tabular}

Source: Own study on the basis of Statistical Yearbooks of Lower Silesia 1999-2010, Statistical Office, Wrocław, 2000-2011 and the portal of the local data bank available at www.stat.gov.pl 
Figure 5. Dynamics of quantitative changes in the foreign capital of entities with foreign capital vs dynamics of changes in GDP in Lower Silesia in the years 1999-2011

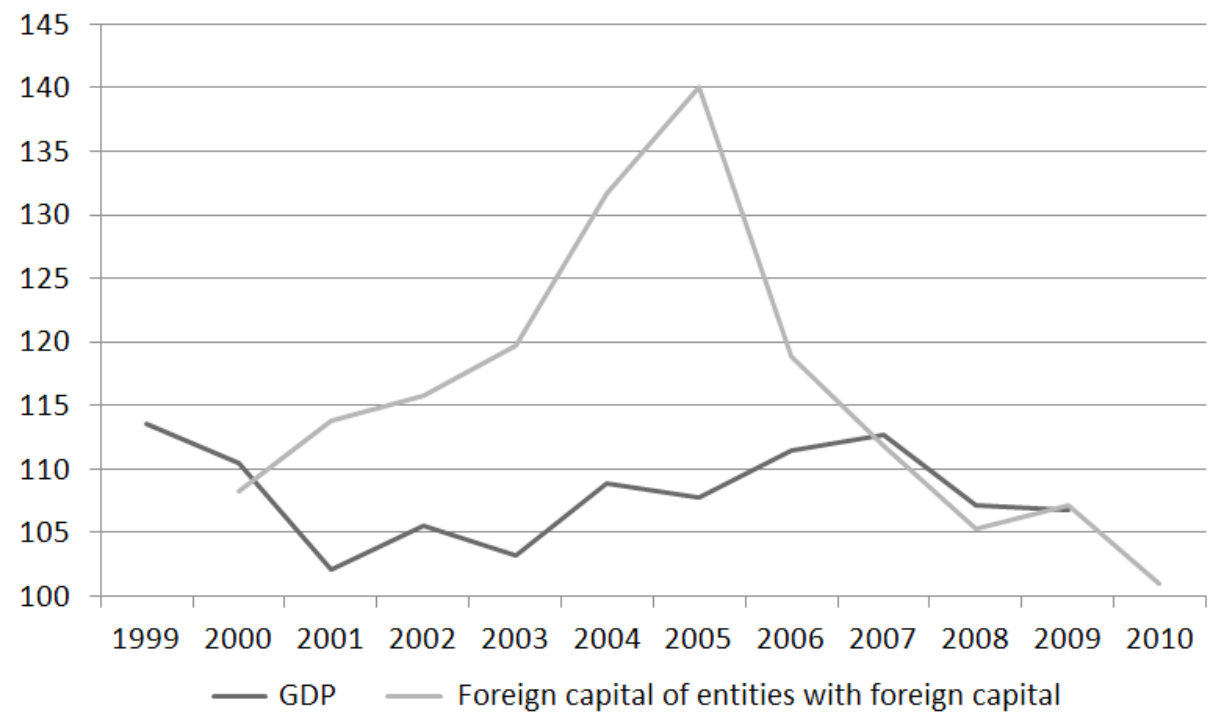

Source: Own study on the basis of Statistical Yearbooks of Lower Silesia 1999-2010, Statistical Office, Wrocław, 2000-2011 and the portal of the local data bank available at www.stat.gov.pl

\section{Investments of entities with foreign capital vs GDP}

As Table 4 and Figure 6 indicate, a relatively stable GDP was accompanied by considerable fluctuations in the investment expenditures of entities with foreign capital. Between analysed categories, it is difficult to observe any relations; thus, the impact of investment expenditure on GDP by entities with foreign capital was insignificant.

Table 4. Dynamics of quantitative changes in the investment expenditure of entities with foreign capital vs dynamics of changes in GDP in Lower Silesia in the years 1999-2011

\begin{tabular}{|l|l|l|l|l|l|l|l|l|l|l|l|l|}
\hline & 1999 & 2000 & 2001 & 2002 & 2003 & 2004 & 2005 & 2006 & 2007 & 2008 & 2009 & 2010 \\
\hline GDP & 113.57 & 110.52 & 102.08 & 105.5 & 103.27 & 108.85 & 107.83 & 111.48 & 112.7 & 107.1 & 106.80 & no data \\
\hline $\begin{array}{l}\text { Investment } \\
\text { expenditure of } \\
\text { entities with } \\
\text { foreign capital }\end{array}$ & - & 78.6 & 180.9 & 71.5 & 87.3 & 153.8 & 149.9 & 153.8 & 108.3 & 63.9 & 83.3 & 118.1 \\
\hline
\end{tabular}

Source: Own study on the basis of Statistical Yearbooks of Lower Silesia 1999-2010, Statistical Office, Wrocław, 2000-2011 and the portal of the local data bank available at www.stat.gov.pl 
Figure 6. Dynamics of quantitative changes in the investment expenditure of entities with foreign capital vs dynamics of changes in GDP in Lower Silesia in the years 1999-2011

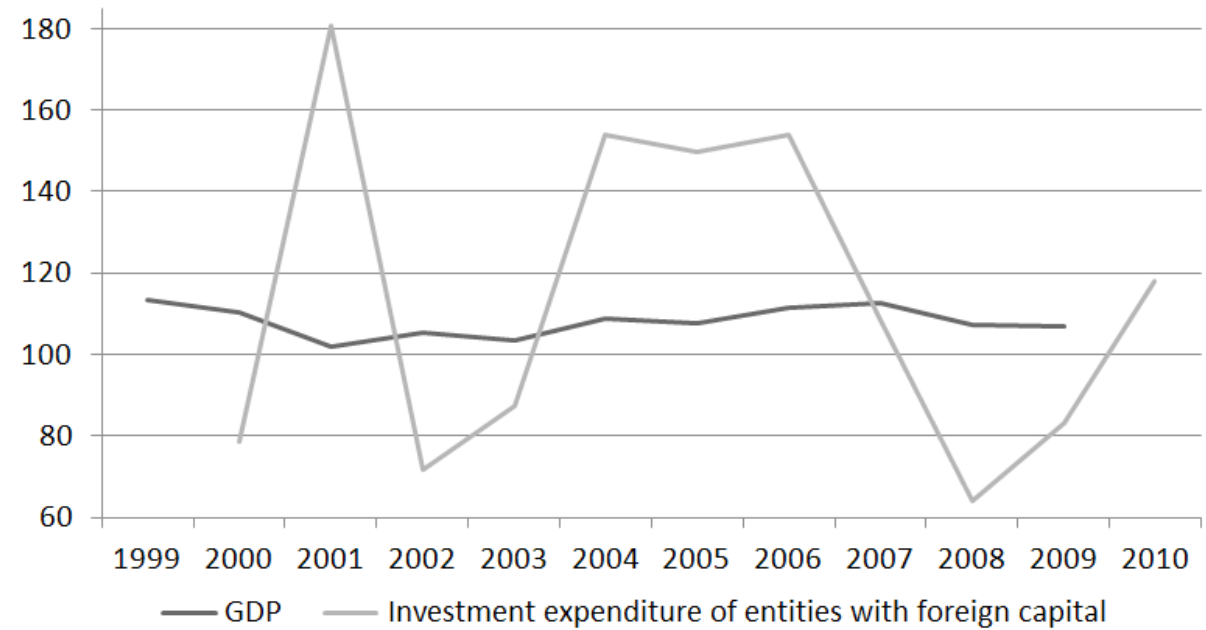

Source: Own study on the basis of Statistical Yearbooks of Lower Silesia 1999-2010, Statistical Office, Wrocław, 2000-2011 and the portal of the local data bank available at www.stat.gov.pl

\section{The number of employees employed in entities with foreign capital vs GDP}

Taking into account the data provided in Table 5, one may observe a clear convergence between the quantitative changes in the number of employees in foreign capital entities and changes in GDP. What can be easily observed from Figure 7 is that the fluctuations in GDP were also accompanied by fluctuations in the entities' employment levels. Thus, a conclusion may be drawn that both categories interacted.

Table 5. Dynamics of quantitative changes in the number of employees employed in entities with foreign capital vs dynamics of changes in GDP in Lower Silesia in the years 1999-2011

\begin{tabular}{|l|l|l|l|l|l|l|l|l|l|l|l|l|}
\hline & 1999 & 2000 & 2001 & 2002 & 2003 & 2004 & 2005 & 2006 & 2007 & 2008 & 2009 & 2010 \\
\hline GDP & 113.57 & 110.52 & 102.08 & 105.5 & 103.27 & 108.85 & 107.83 & 111.48 & 112.7 & 107.1 & 106.80 & $\begin{array}{l}\text { no } \\
\text { data }\end{array}$ \\
\hline $\begin{array}{l}\text { Employees } \\
\text { employed in } \\
\text { entities with } \\
\text { foreign capital }\end{array}$ & - & 106.3 & 97.0 & 107.8 & 107.1 & 112.7 & 110.0 & 116.9 & 116.2 & 110.2 & 92.5 & 105.3 \\
\hline
\end{tabular}

Source: Own study on the basis of Statistical Yearbooks of Lower Silesia 1999-2010, Statistical Office, Wrocław, 2000-2011 and the portal of the local data bank available at www.stat.gov.pl 
Figure 7. Dynamics of quantitative changes in the number of employees employed in entities with foreign capital vs dynamics of changes in GDP in Lower Silesia in the years 1999-2011

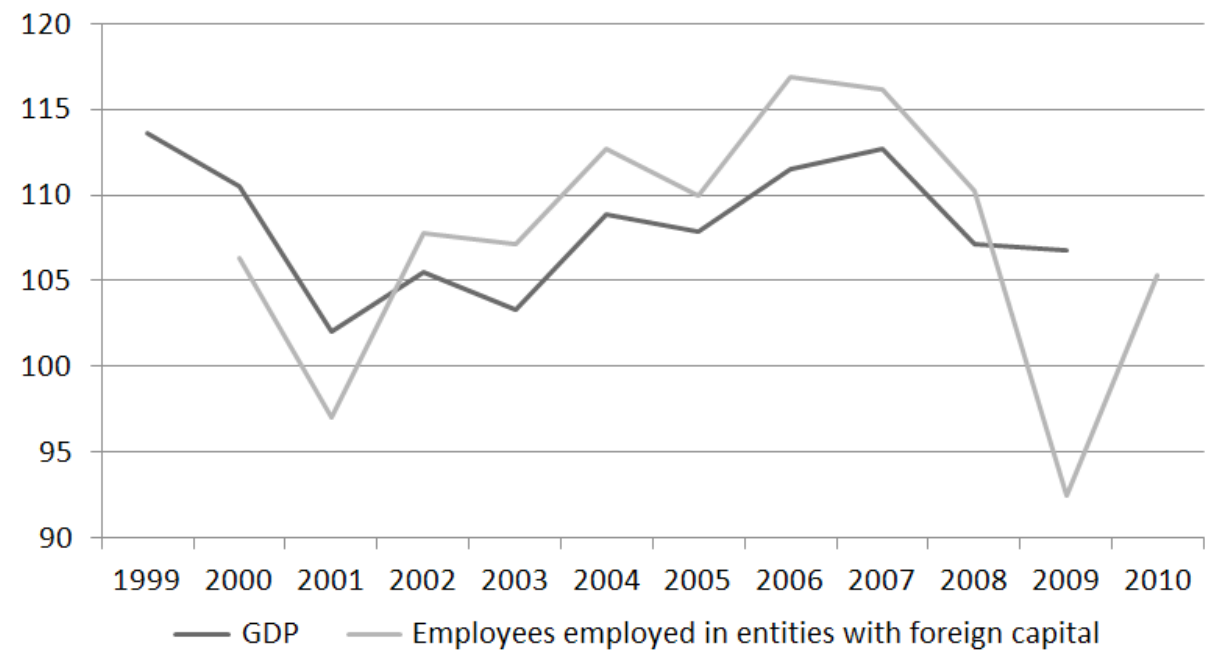

Source: Own study on the basis of Statistical Yearbooks of Lower Silesia 1999-2010, Statistical Office, Wrocław, 2000-2011 and the portal of the local data bank available at www.stat.gov.pl

\section{Location of companies with foreign capital participating in Lower Silesia}

The nomenclature of territorial units for statistics (NUTS) specifies and organises the of names of territorial units and symbols assigned to them. This nomenclature occurs on particular levels of Poland's territorial divisions, and is used to collect statistical data, gathering, storage of and elaborating on the data collected, and announcing, making available and publicising the results of statistical research according to territories, divides Lower Silesia into five subregions: Jelenia Góra, Legnica and Głogów, the city of Wrocław, a further subregion of Wrocław, and still another subregion of Wrocław. The subregions of the highest investment attractiveness for industrial activities include the two compact areas situated in the south of Poland. One of the two areas mentioned above is situated around Upper Silesia and in the western part of Lesser Poland; the other one is located around Wrocław, Jelenia Góra and Wałbrzych, namely, industrial areas of Lower Silesia. These areas are distinguished by long industrial traditions, and, thus, a have a well-developed industrial sector, specialist labour market and relatively good transport networks thanks to the A- 4 motorway. The highest level of investment attractiveness are mainly metropolitan subregions. They include the largest Polish cities, having considerable human resources of 
high and diverse competences and large markets. Apart from this, the largest cities provide good transport opportunities and a well-developed economic infrastructure. The subregions most attractive for investments in advanced technologies are also dominated by metropolitan subregions. This is where both the infrastructure and research and development staff are concentrated. The labour market includes specialists educated at local universities and specialists who are encouraged to migrate to these metropolitan areas thanks to good living conditions, including developed cultural surroundings. These areas are characterised by the best developed tele-information infrastructure and relatively good passenger transportation [Nowicki 2011, pp. 5-6].

Companies with foreign capital in Lower Silesia are concentrated in urban agglomerations which were provincial cities not long ago in particular in Wrocław, where almost $50 \%$ of companies with foreign capital in Lower Silesia are situated (see Table 6, Maps 1, 2 and 3). The concentration of a large number of such companies in whole subregions usually stems from the presence of a large city in the region.

However, it is the subregion of Wałbrzych that has recorded the highest increases and it has recently caught up with the subregion of Wrocław despite the fact that Wałbrzych had previously attracted 30 times fewer companies than Wrocław.

Table 6. Companies with participation of foreign capital in Lower Silesia, in a division into subregions in the years 2000, 2005 and 2010

\begin{tabular}{|l|l|l|l|}
\hline & 2000 & 2005 & 2010 \\
\hline Lower Silesia & $\mathbf{4 3 7 9}$ & $\mathbf{5 3 7 5}$ & $\mathbf{6 5 2 1}$ \\
\hline Subregion of Jelenia Góra & 915 & 1077 & 1194 \\
\hline Subregion of Legnica and Głogów & 349 & 417 & 462 \\
\hline Subregion the city of Wrocław & 1973 & 2416 & 3134 \\
\hline Subregion of Wrocław & 481 & 666 & 835 \\
\hline Subregion of Wałbrzych & 663 & 948 & 984 \\
\hline
\end{tabular}

Source: Own study on the basis of Statistical Yearbooks of Lower Silesia 2000, 2005 and 2010, Statistical Office, Wrocław 2001, 2006 and 2011 and Lower Silesia. Subregions. Districts. Communes. 2000, 2005 and 2010, Statistical Office, Wrocław 2001, 2006 and 2011 
Map 1. Distribution of companies with participation of foreign capital in Lower Silesia, in a division into subregions in 2000

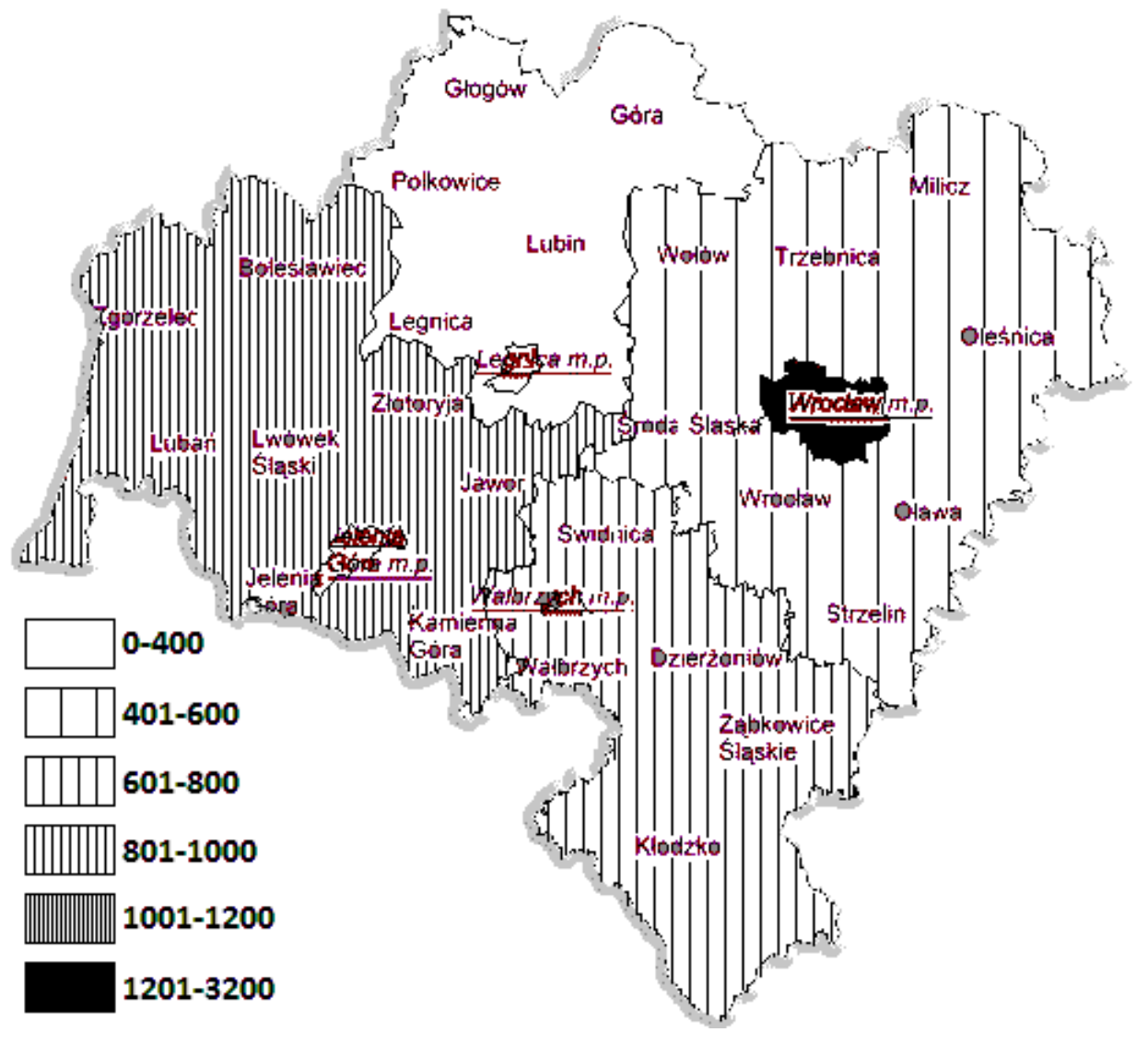

Source: Own study on the basis of Statistical Yearbooks of Lower Silesia 2000, 2005 and 2010, Statistical Office, Wrocław 2001, 2006 and 2011 and Lower Silesia. Subregions. Districts. Communes. 2000, 2005 and 2010, Statistical Office, Wrocław 2001, 2006 and 2011 
Map 2. Distribution of companies with participation of foreign capital in Lower Silesia, in a division into subregions in 2005

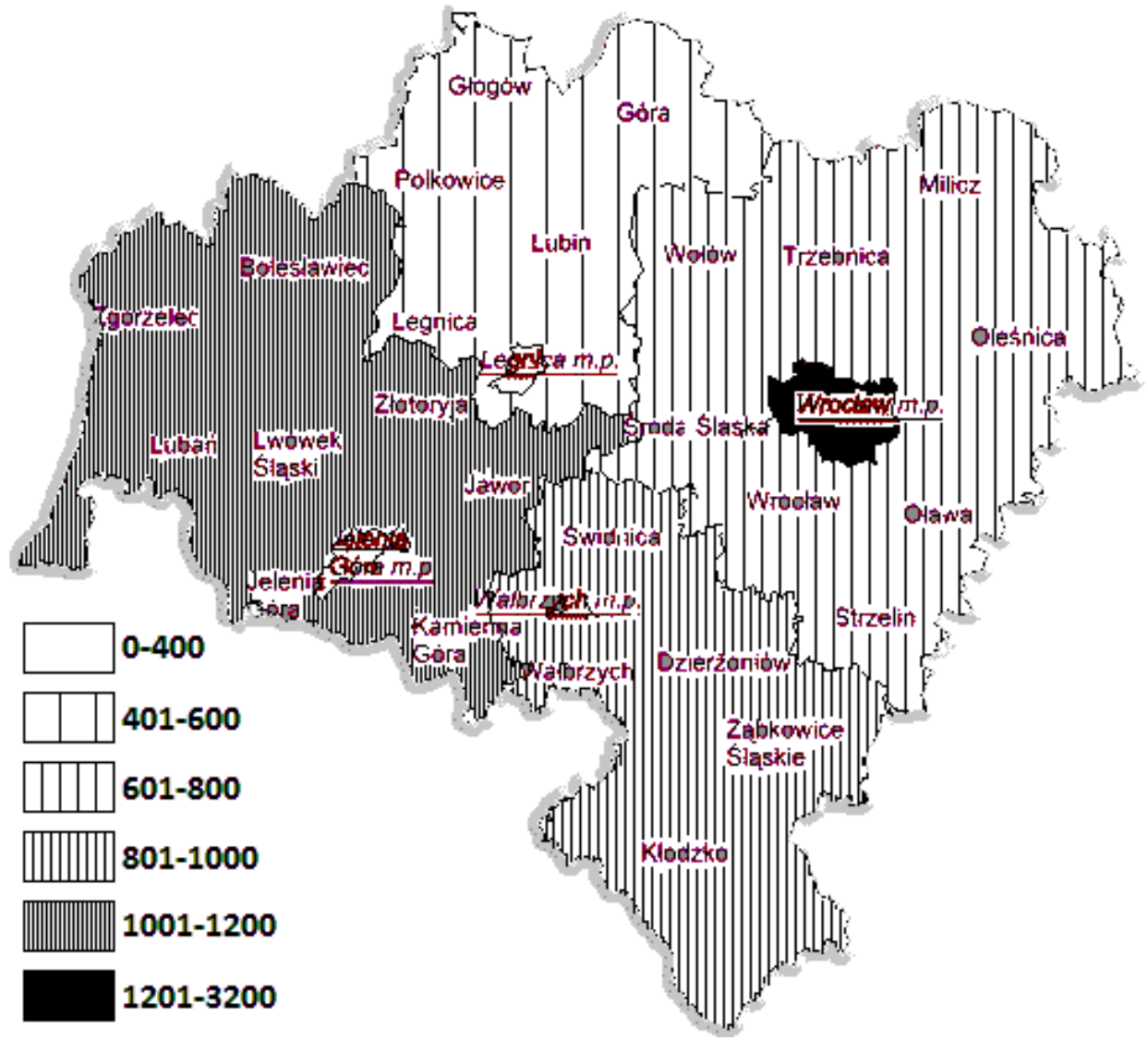

Source: Own study on the basis of Statistical Yearbooks of Lower Silesia 2000, 2005 and 2010, Statistical Office, Wrocław 2001, 2006 and 2011 and Lower Silesia. Subregions. Districts. Communes. 2000, 2005 and 2010, Statistical Office, Wrocław 2001, 2006 and 2011 
Map 3. Distribution of companies with participation of foreign capital in Lower Silesia, in a division into subregions in 2010

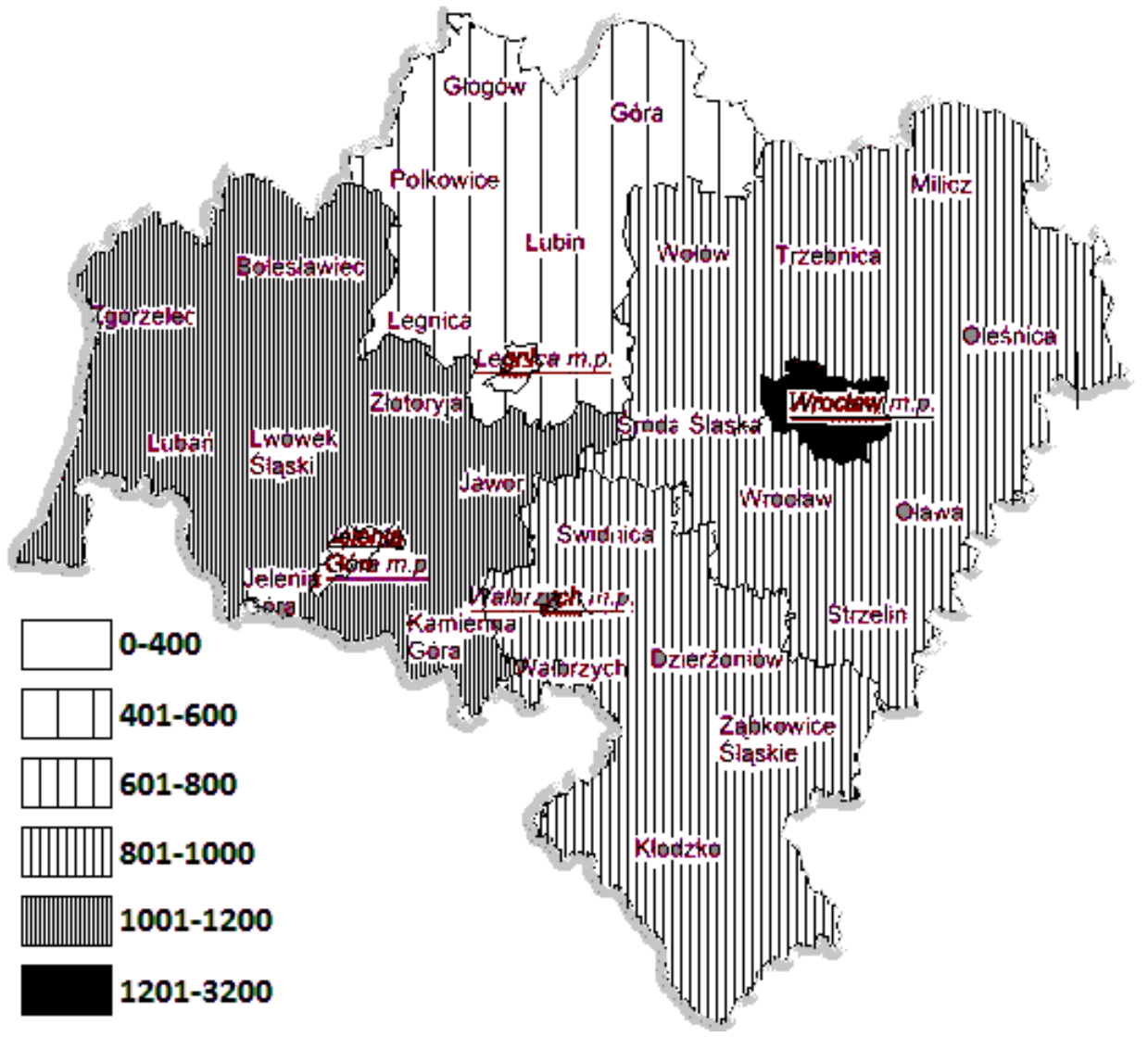

Source: Own study on the basis of Statistical Yearbooks of Lower Silesia 2000, 2005 and 2010, Statistical Office, Wrocław 2001, 2006 and 2011 and Lower Silesia. Subregions. Districts. Communes. 2000, 2005 and 2010, Statistical Office, Wrocław 2001, 2006 and 2011

The distribution of companies using foreign capital in Lower Silesia may be analysed more thoroughly by considering their location in a division into districts. Table 7 and Maps 4, 5 and 6 present interesting changes. The largest increases were observed in the districts of Wrocław, Świdnica and Jelenia Góra, and, subsequently, in the districts of Zgorzelec and Kłodzko. The other districts experienced stagnation, with insignificant increases of a dozen companies or so within a five-year period. 
Table 7. Companies with participation of foreign capital in Lower Silesia, in a division into districts in the years 2000, 2005 and 2010

\begin{tabular}{|c|c|c|c|}
\hline & 2000 & 2005 & 2010 \\
\hline POLAND & 43737 & 54336 & 68211 \\
\hline Lower Silesia & 4379 & 5375 & 6521 \\
\hline District of Bolesławiec & 112 & 127 & 142 \\
\hline District of Dzierżoniów & 83 & 104 & 116 \\
\hline District of Głógów & 73 & 82 & 92 \\
\hline District of Góra & 13 & 17 & 21 \\
\hline District of Jawor & 43 & 60 & 65 \\
\hline District of Jelenia Góra & 171 & 192 & 219 \\
\hline District of Kamienna Góra & 51 & 64 & 72 \\
\hline District of Kłodzko & 140 & 182 & 179 \\
\hline District of Legnica & 41 & 42 & 44 \\
\hline District of Lubań & 70 & 89 & 105 \\
\hline District of Lubin & 61 & 75 & 85 \\
\hline District of Lwówek Śląski & 46 & 59 & 62 \\
\hline District of Milicz & 22 & 28 & 26 \\
\hline District of Oleśnica & 64 & 86 & 94 \\
\hline District of Oława & 48 & 86 & 57 \\
\hline District of Polkowice & 35 & 49 & 45 \\
\hline District of Strzelin & 45 & 62 & 76 \\
\hline District of Środa Śląska & 40 & 64 & 82 \\
\hline District of Świdnica & 220 & 260 & 287 \\
\hline District of Trzebnica & 69 & 92 & 104 \\
\hline District of Wałbrzych & 42 & 197 & 198 \\
\hline District of Wołów & 40 & 42 & 56 \\
\hline District of Wrocław & 153 & 206 & 340 \\
\hline District of Ząbkowice Śląskie & 43 & 56 & 61 \\
\hline District of Zgorzelec & 110 & 143 & 166 \\
\hline District of Złotoryja & 42 & 48 & 52 \\
\hline Jelenia Góra & 270 & 295 & 311 \\
\hline Legnica & 126 & 152 & 175 \\
\hline Wałbrzych & 133 & 149 & 143 \\
\hline Wrocław & 1973 & 2416 & 3134 \\
\hline
\end{tabular}

Source: Own study on the basis of Statistical Yearbooks of Lower Silesia 2000, 2005 and 2010, Statistical Office, Wrocław 2001, 2006 and 2011 and Lower Silesia. Subregions. Districts. Communes. 2000, 2005 and 2010, Statistical Office, Wrocław 2001, 2006 and 2011 
Map 4. Distribution of companies with participation of foreign capital in Lower Silesia, in a division into districts in 2000

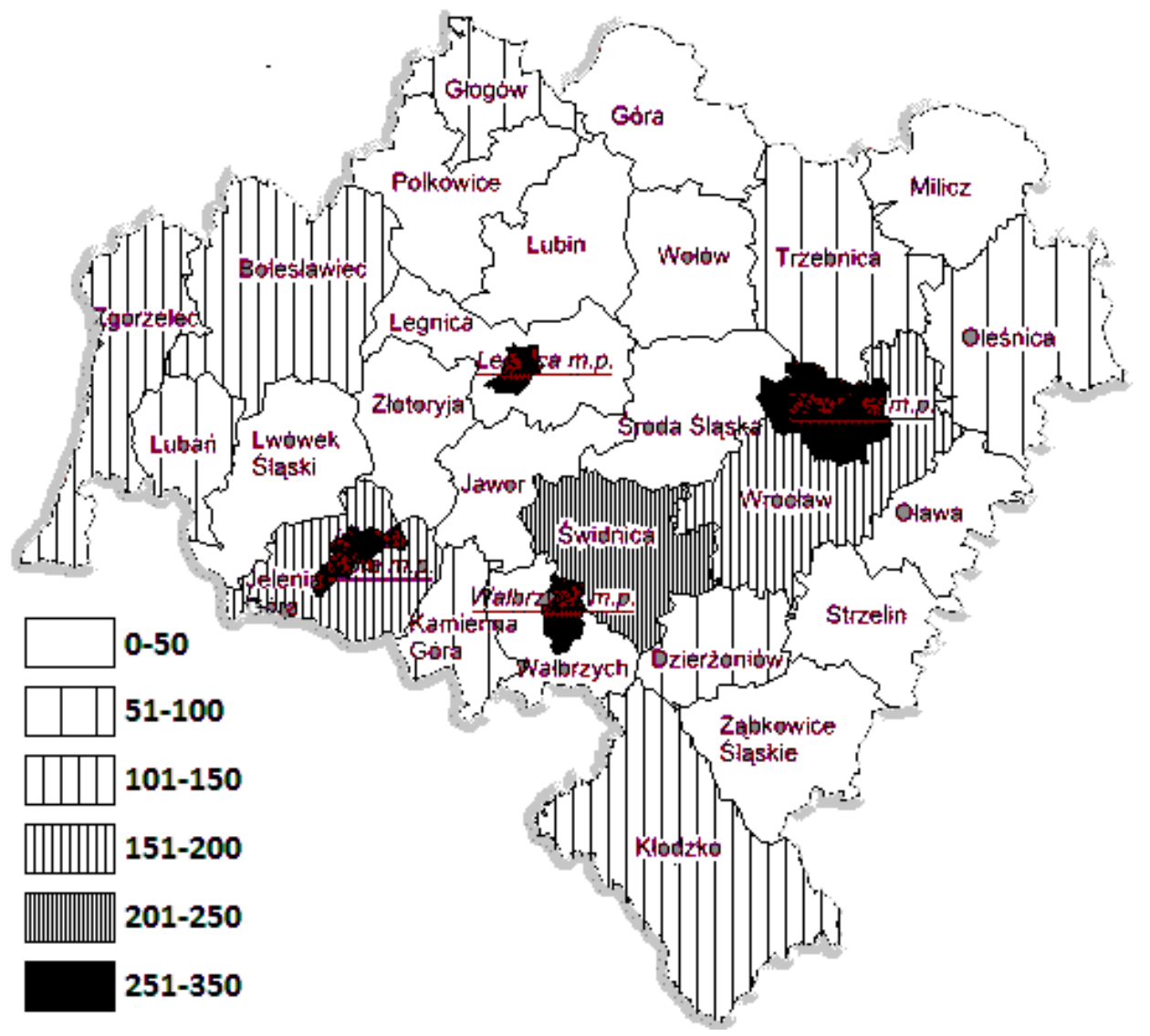

Source: Own study on the basis of Statistical Yearbooks of Lower Silesia 2000, 2005 and 2010, Statistical Office, Wrocław 2001, 2006 and 2011 and Lower Silesia. Subregions. Districts. Communes. 2000, 2005 and 2010, Statistical Office, Wrocław 2001, 2006 and 2011 
Map 5. Distribution of companies with participation of foreign capital in Lower Silesia, in a division into districts in 2005

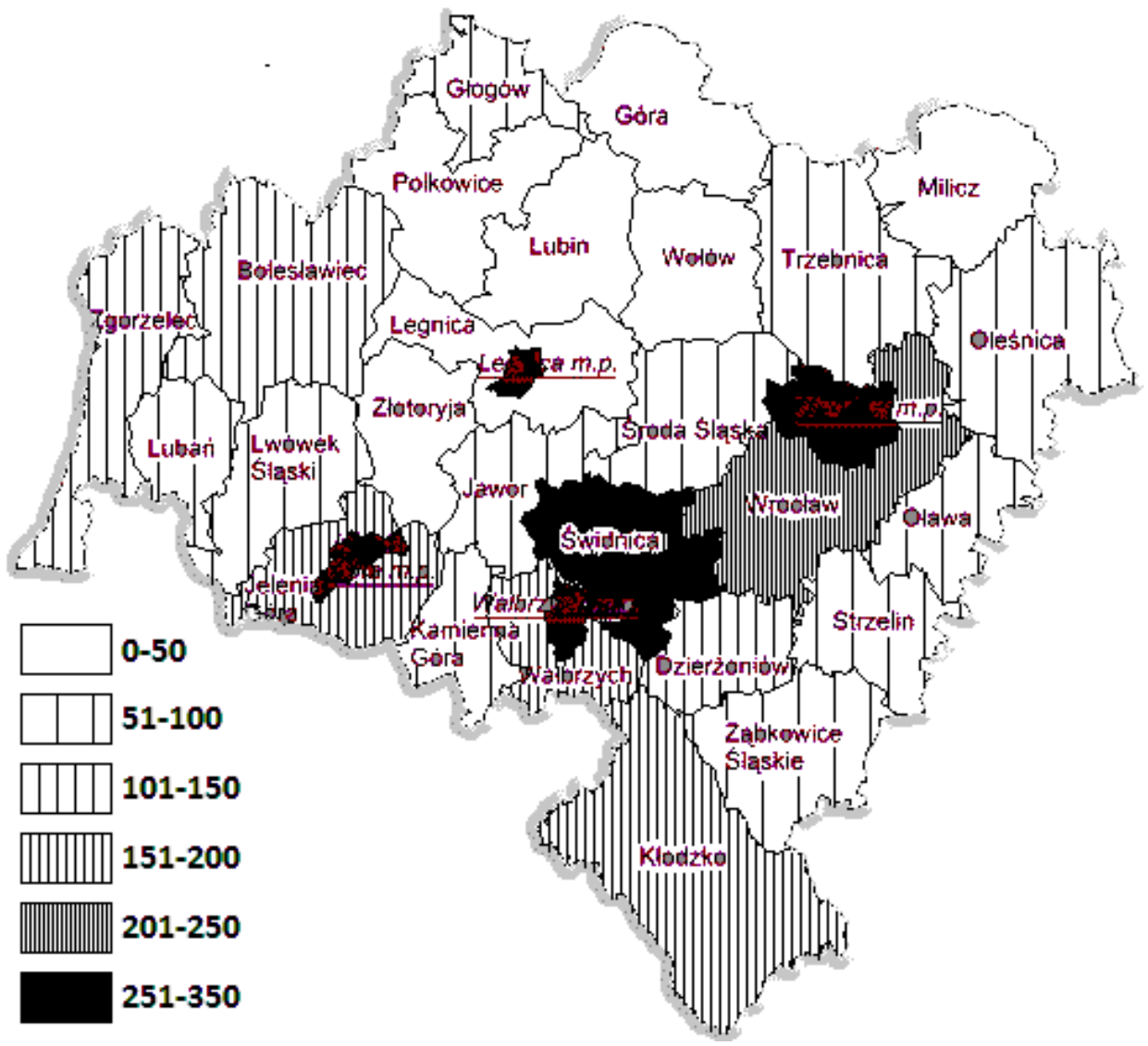

Source: Own study on the basis of Statistical Yearbooks of Lower Silesia 2000, 2005 and 2010, Statistical Office, Wrocław 2001, 2006 and 2011 and Lower Silesia. Subregions. Districts. Communes. 2000, 2005 and 2010, Statistical Office, Wrocław 2001, 2006 and 2011 
Map 6. Distribution of companies with participation of foreign capital in Lower Silesia, in a division into districts in 2010

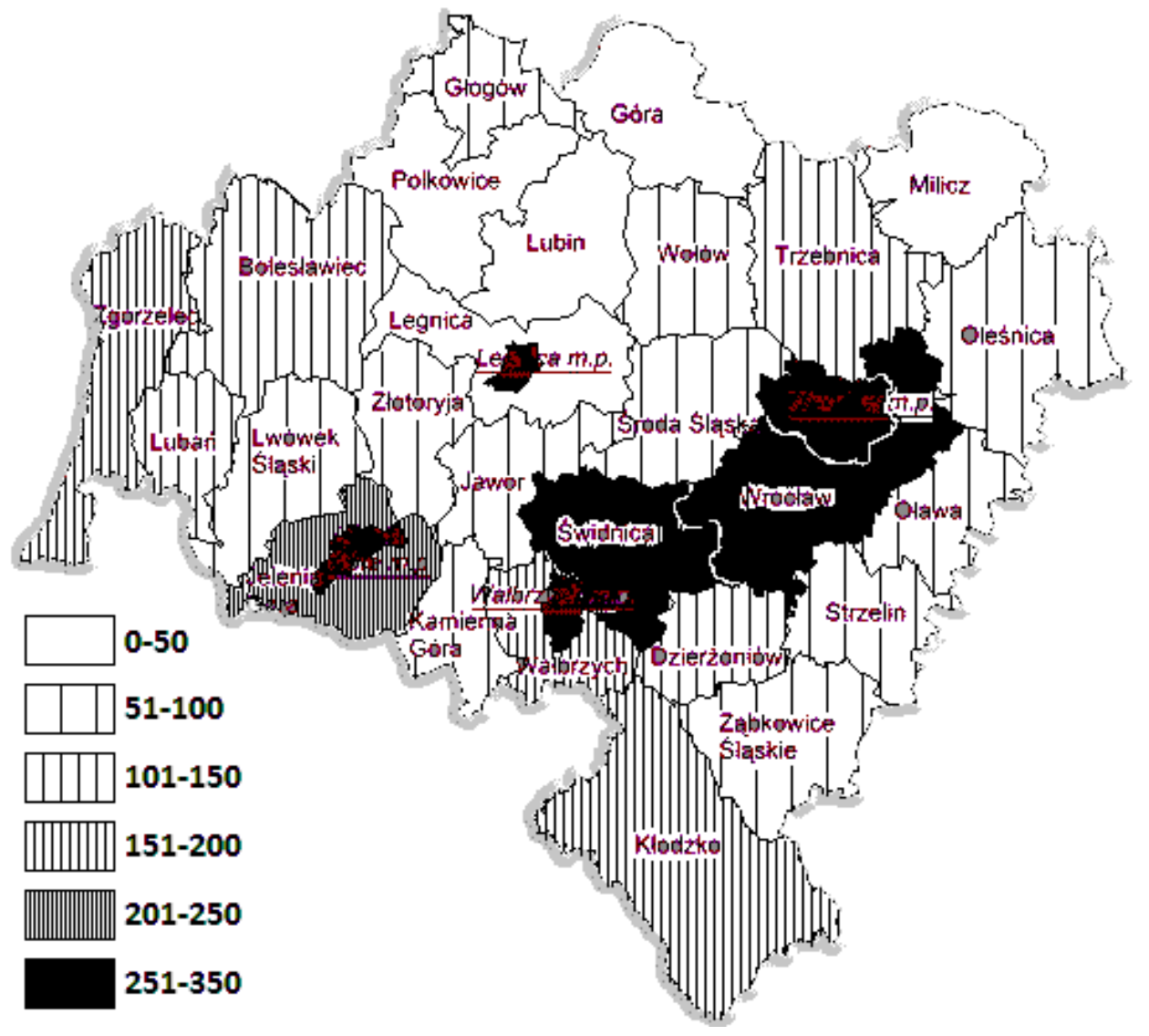

Source: Own study on the basis of Statistical Yearbooks of Lower Silesia 2000, 2005 and 2010, Statistical Office, Wrocław 2001, 2006 and 2011 and Lower Silesia. Subregions. Districts. Communes. 2000, 2005 and 2010, Statistical Office, Wrocław 2001, 2006 and 2011

According to the analysis above, despite a friendly national policy (embodied, inter alia, by the establishment of SEZ's), the number of investors attracted to the areas suffering from negative economic transformations was not as high as expected.

Number of employees employed in entities with foreign capital vs the total number of employees

Foreign investments also affect the labour market; they may activate local labour markets and the local economy thanks to the so-called multiplier effect. 
The employment level in a province increased insignificantly within 11 years by about $10 \%$, whereas it doubled in entities with foreign capital. Additionally, the share of people employed in entities with foreign capital in the total number of employees doubled, reaching 18.6\% in 2010 (Table 8a, Figure 8). It is undoubted evidence that foreign capital plays a more and more dominant role in shaping the labour market in Lower Silesia.

Table 8a. Number of employees employed in companies with foreign capital vs the total number of employees in Lower Silesia in the years 1999-2010

\begin{tabular}{|l|l|l|l|l|l|l|l|l|l|l|l|l|}
\hline & 1999 & 2000 & 2001 & 2002 & 2003 & 2004 & 2005 & 2006 & 2007 & 2008 & 2009 & 2010 \\
\hline $\begin{array}{l}\text { Total } \\
\text { number of } \\
\text { employees }\end{array}$ & 701464 & 642046 & 619463 & 584805 & 656422 & 650724 & 673981 & 696113 & 733625 & 770505 & 757207 & 782782 \\
\hline $\begin{array}{l}\text { Number of } \\
\text { employees } \\
\text { employed } \\
\text { in entities } \\
\text { with foreign } \\
\text { capital }\end{array}$ \\
\hline $\begin{array}{l}\text { Share of the } \\
\text { employees } \\
\text { employed } \\
\text { in entities } \\
\text { with foreign } \\
\text { capital in } \\
\text { the total } \\
\text { number of } \\
\text { employees } \\
\text { \%) }\end{array}$
\end{tabular}

Source: Own study on the basis of Statistical Yearbooks of Lower Silesia 1999-2010, Statistical Office, Wrocław, 2000-2011 and the portal of the local data bank available at www.stat.gov. pl and Economic Activity of Entities with Foreign Capital 1999-2011, GUS, Warszawa 20002012 
Figure 8. Number of employees employed in companies with foreign capital vs the total number of employees in Lower Silesia in the years 1999-2010

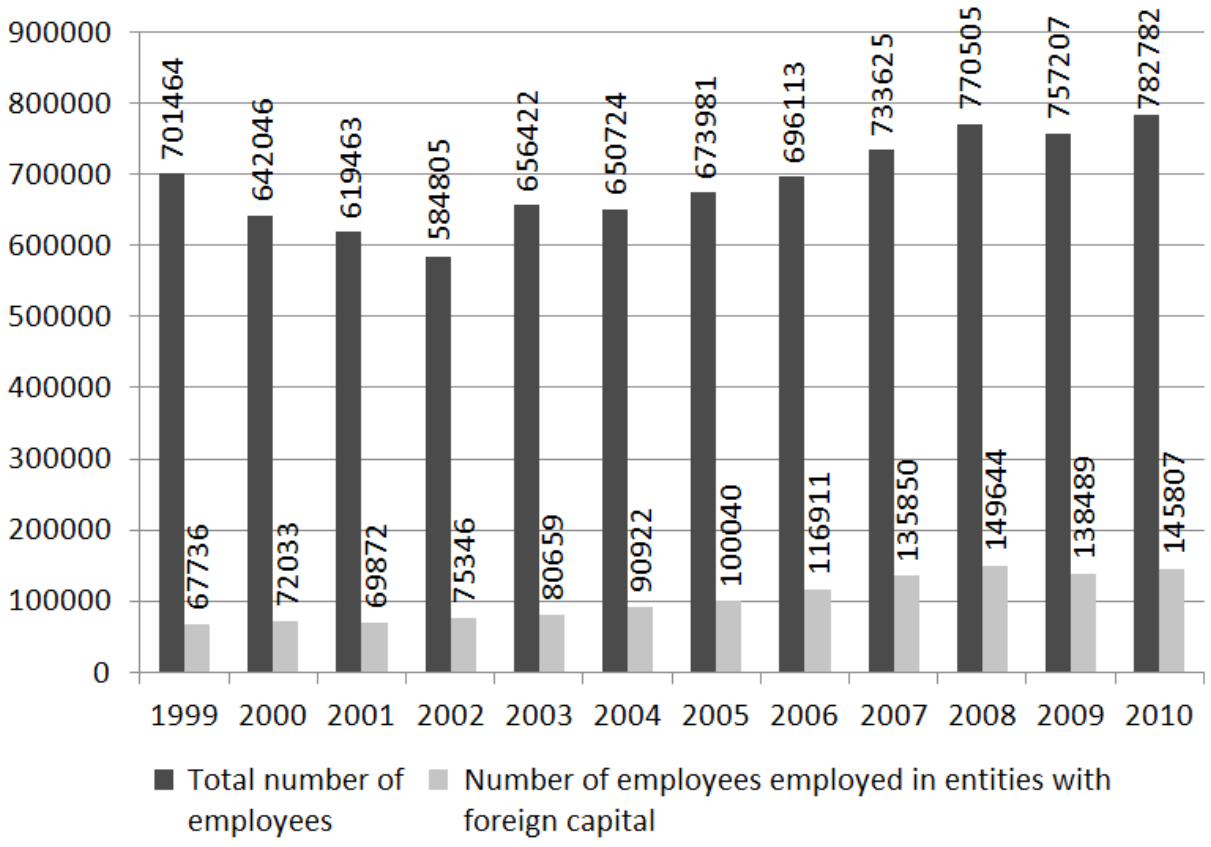

Source: Own study on the basis of Statistical Yearbooks of Lower Silesia 1999-2010, Statistical Office, Wrocław, 2000-2011 and the portal of the local data bank available at www.stat.gov. pl and Economic Activity of Entities with Foreign Capital 1999-2011, GUS, Warszawa 20002012

The dynamics of this process are presented in Table $8 \mathrm{~b}$ and Figure 10. Here one may also observe convergence of the categories, with the first and fifth year excepted.

Table 8b. Dynamics of quantitative changes in the number of employees employed in entities with foreign capital vs dynamics of quantitative changes in the total number of employees in Lower Silesia in the years 1999-2010 (previous year $=100)$

\begin{tabular}{|l|l|l|l|l|l|l|l|l|l|l|l|l|}
\hline & 1999 & 2000 & 2001 & 2002 & 2003 & 2004 & 2005 & 2006 & 2007 & 2008 & 2009 & 2010 \\
\hline $\begin{array}{l}\text { Total number of } \\
\text { employees }\end{array}$ & - & 91.5 & 96.5 & 94.4 & 112.2 & 99.1 & 103.6 & 103.3 & 105.4 & 105.0 & 98.3 & 103.4 \\
\hline
\end{tabular}




\begin{tabular}{|l|l|l|l|l|l|l|l|l|l|l|l|l|}
\hline $\begin{array}{l}\text { Number of } \\
\text { employees } \\
\text { employed in } \\
\text { entities with } \\
\text { foreign capital }\end{array}$ & - & 106.3 & 97.0 & 107.8 & 107.1 & 112.7 & 110.0 & 116.9 & 116.2 & 110.2 & 92.5 & 105.3 \\
\hline
\end{tabular}

Source: Own study on the basis of Statistical Yearbooks of Lower Silesia 1999-2010, Statistical Office, Wrocław, 2000-2011 and the portal of the local data bank available at www.stat.gov. pl and Economic Activity of Entities with Foreign Capital 1999-2011, GUS, Warszawa 20002012

Figure 9. Dynamics of quantitative changes in the number of employees employed in entities with foreign capital vs dynamics of quantitative changes in the total number of employees in Lower Silesia in the years 1999-2010 (previous year $=100$ )

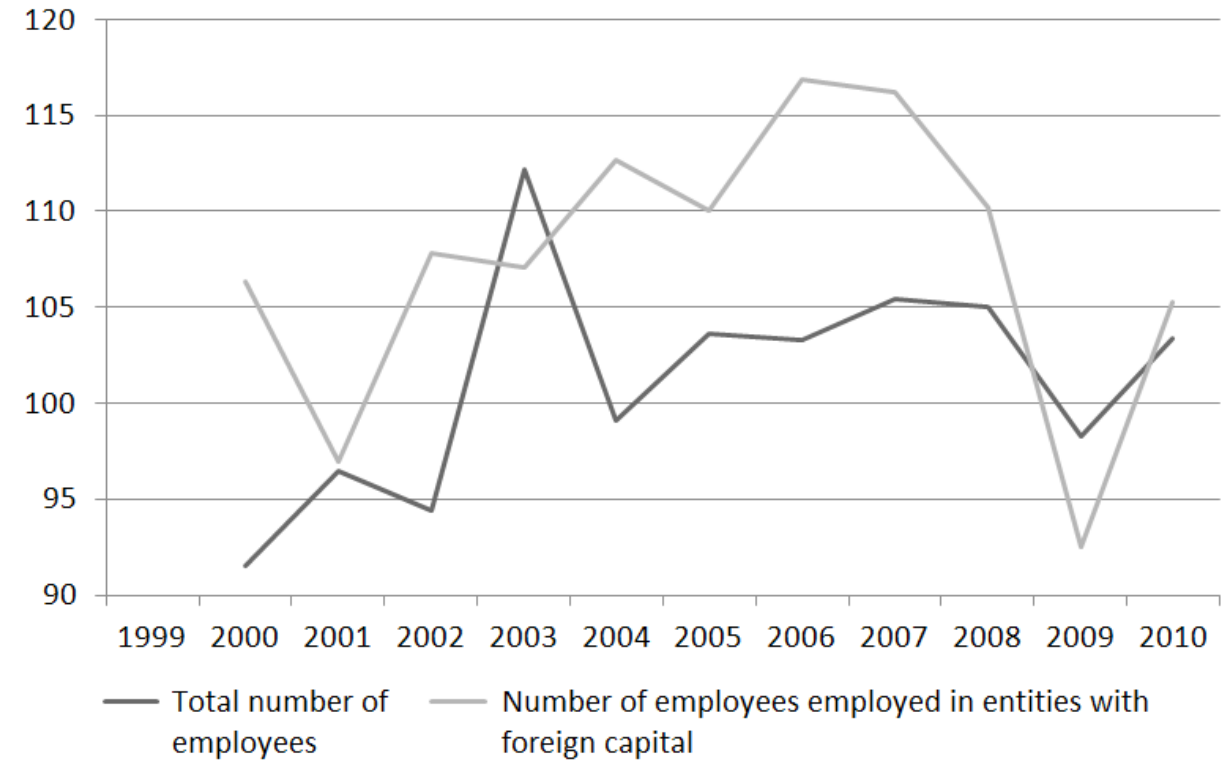

Source: Own study on the basis of Statistical Yearbooks of Lower Silesia 1999-2010, Statistical Office, Wrocław, 2000-2011 and the portal of the local data bank available at www.stat.gov. pl and Economic Activity of Entities with Foreign Capital 1999-2011, GUS, Warszawa 20002012

Investment expenditure of entities with foreign capital vs total expenditure of enterprises

Another equally important effect of foreign investment on regional development is an increase in total investments, of which $\mathrm{EE}$ is a positive 
phenomenon when you take into account the low internal capital accumulation caused (inter alia) by negligible national savings.

In general, Polish companies are not able to cope with global competition without a strategic investor having access to international markets [Czerwińska 2001, p. 2].

What stems from Table 9a is that the total investment expenditure incurred by enterprises increased insignificantly, whereas the investment expenditure incurred by foreign investors increased by more than $100 \%$. Thus, the investment expenditure incurred by entities with foreign capital, being a regional development factor, was more and more significant, reaching $80 \%$ in 2006.

Table 9a. Investment expenditure incurred by entities with foreign capital vs total investment expenditure incurred by companies in Lower Silesia in the years 1999-2010 in million PLN

\begin{tabular}{|l|l|l|l|l|l|l|l|l|l|l|l|l|}
\hline $\begin{array}{l}\text { Total } \\
\text { investment } \\
\text { expenditure } \\
\text { incurred by } \\
\text { enterprises }\end{array}$ & no data & 6791.1 & 8578.5 & 6173.3 & 5402.9 & 6658.6 & 7621.0 & 9818.2 & 11335.5 & 11659.2 & 10555.2 & 9884.6 \\
\hline $\begin{array}{l}\text { Investment } \\
\text { expenditure } \\
\text { incurred by } \\
\text { entities with } \\
\text { foreign capital }\end{array}$ & 2458.6 & 1936.2 & 3503.1 & 2503.1 & 2186.4 & 3362.2 & 5041.4 & 7753.7 & 8396.3 & 5366.9 & 4472.7 & 5280.7 \\
\hline $\begin{array}{l}\text { Share of the } \\
\text { investment } \\
\text { expenditure } \\
\text { incurred by } \\
\text { entities with } \\
\text { foreign capital } \\
\text { in the total } \\
\text { investment } \\
\text { expenditure } \\
\text { incurred by } \\
\text { enterprises }\end{array}$
\end{tabular}

Source: Own study on the basis of Statistical Yearbooks of Lower Silesia 1999-2010, Statistical Office, Wrocław, 2000-2011 and the portal of the local data bank available at www.stat.gov. pl and Economic Activity of Entities with Foreign Capital 1999-2011, GUS, Warszawa 20002012 
Figure 10. Investment expenditure incurred by entities with foreign capital vs the total expenditure incurred by companies in Lower Silesia in the years 19992010 in million PLN

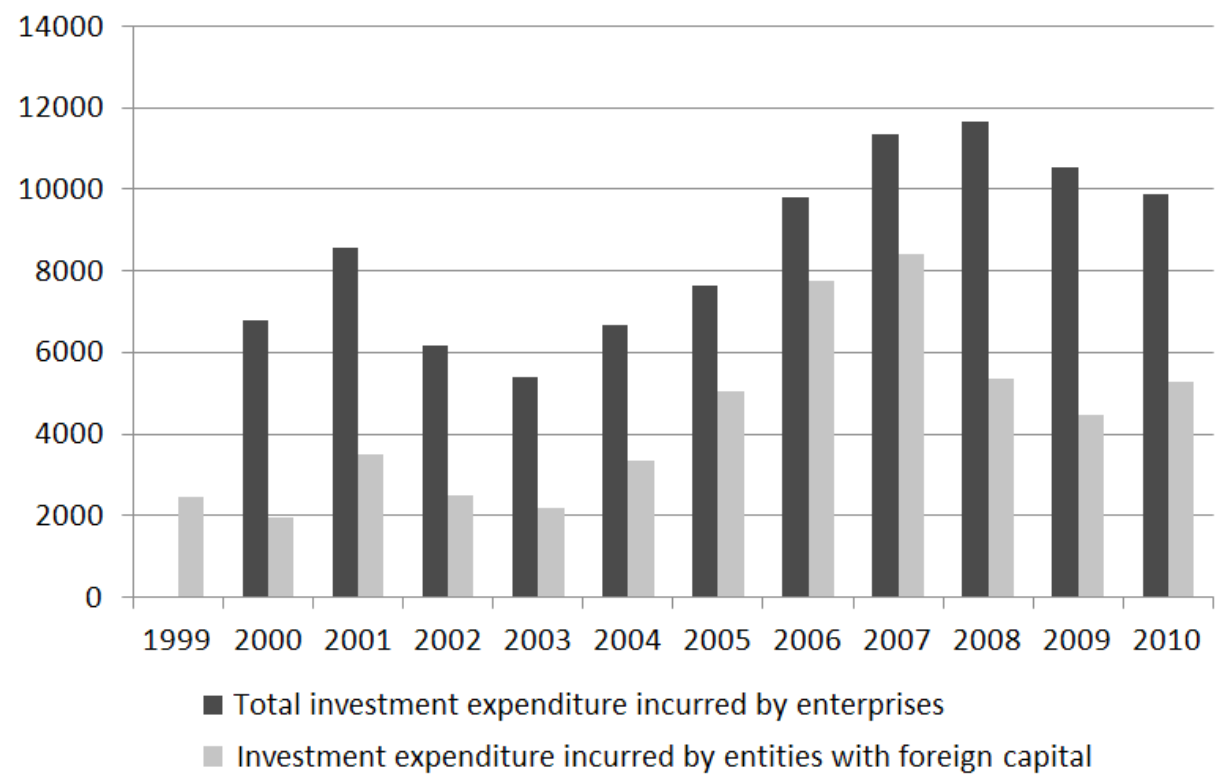

Source: Own study on the basis of Statistical Yearbooks of Lower Silesia 1999-2010, Statistical Office, Wrocław, 2000-2011 and the portal of the local data bank available at www.stat.gov. pl and Economic Activity of Entities with Foreign Capital 1999-2011, GUS, Warszawa 20002012

Despite certain irregularities, the convergence of changes in the whole period confirms the positive impact of investment expenditures incurred by entities with foreign capital (Table 9b and Figure 11).

Table 9b. Dynamics of quantitative changes in the investment expenditure incurred by entities with foreign capital vs dynamics of quantitative changes in the total investment expenditure incurred by enterprises in Lower Silesia in the years 1999-2010 (previous year $=100$ )

\begin{tabular}{|l|l|l|l|l|l|l|l|l|l|l|l|l|}
\hline & 1999 & 2000 & 2001 & 2002 & 2003 & 2004 & 2005 & 2006 & 2007 & 2008 & 2009 & 2010 \\
\hline $\begin{array}{l}\text { Investment } \\
\text { expenditure } \\
\text { incurred by } \\
\text { entities with } \\
\text { foreign capital }\end{array}$ & - & 78.6 & 180.9 & 71.5 & 87.3 & 153.8 & 149.9 & 153.8 & 108.3 & 63.9 & 83.3 & 118.1 \\
\hline
\end{tabular}




\begin{tabular}{|l|l|l|l|l|l|l|l|l|l|l|l|l|}
\hline $\begin{array}{l}\text { Total investment } \\
\text { expenditure } \\
\text { incurred by } \\
\text { enterprises }\end{array}$ & - & - & 126.3 & 72.0 & 87.5 & 123.2 & 114.4 & 128.8 & 115.4 & 102.8 & 90.5 & 93.6 \\
\hline
\end{tabular}

Source: Own study on the basis of Statistical Yearbooks of Lower Silesia 1999-2010, Statistical Office, Wrocław, 2000-2011 and the portal of the local data bank available at www.stat.gov. pl and Economic Activity of Entities with Foreign Capital 1999-2011, GUS, Warszawa 20002012

Figure 11. Dynamics of quantitative changes in the investment expenditure incurred by entities with foreign capital vs dynamics of quantitative changes in the total expenditure incurred by enterprises in Lower Silesia in the years 1999-2010 (previous year $=100)$

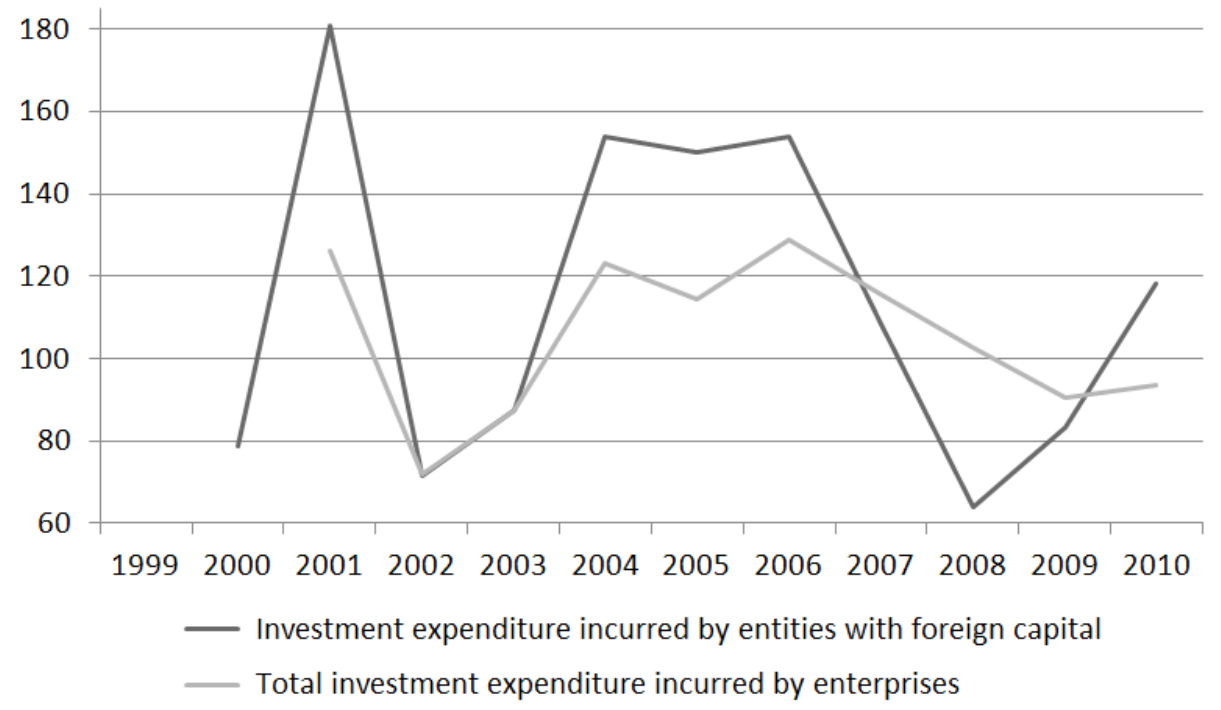

Source: Own study on the basis of Statistical Yearbooks of Lower Silesia 1999-2010, Statistical Office, Wrocław, 2000-2011 and the portal of the local data bank available at www.stat.gov. pl and Economic Activity of Entities with Foreign Capital 1999-2011, GUS, Warszawa 20002012

\section{Final remarks}

The distribution of companies with foreign capital in Lower Silesia shows that companies are concentrated in urban agglomerations which were provincial cities before the administrative reform, in particular Wrocław where almost $50 \%$ of companies with foreign capital in Lower Silesia are situated. In turn, it is the subregion of Wałbrzych that has revealed the highest dynamics 
of increases, and has recently caught up with the subregion of Wrocław despite the fact that Wałbrzych had previously attracted 30 times fewer companies than Wrocław. The largest location increases in the district divisions into were observed in the districts of Wrocław, Świdnica and Jelenia Góra, and subsequently in the districts of Zgorzelec and Kłodzko. The other districts of the region suffered from stagnation, with a dozen companies or so showing insignificant increases within a five-year period, which is evidence of a rather ineffective policy pursued by the state in attracting investors to those areas suffering from negative economic transformation.

Most foreign enterprises operating in Poland establish capital companies and conduct economic activities using the domestic capital. The number of capital companies has systematically increased from the beginning of the period analysed; however, their growth is not as dynamic as is the increase in the total number of commercial companies, which almost doubled. The percentage share of companies boosted by foreign capital in the total number of commercial companies was gradually reduced, which does not mean, though, that foreign investors were less interested in the region but that they were more inclined to invest in large companies. The noticeable convergence of both groups of companies under analysis was accompanied by their diminishing increases.

Despite a decreasing share of foreign capital companies in the total number of commercial companies, entities with foreign capital recorded an investment increase by more than $100 \%$. The total primary capital in Lower Silesia province was doubled, while entities with foreign capital tripled. It is another element confirming that foreign investors are increasingly interested in large investments, which in turn is evidence that they are seriously interested in the region. Interestingly enough, increases in the total primary capital of enterprises and in foreign capital entities fluctuated considerably up to 50 percentage points. What can also be observed here is the convergence of both types of business activity.

The most important effect of direct foreign investments is their impact on GDP. Apart from an increased GDP through production of new goods, direct foreign investments also result in transferring state-of-the-art technologies, know-how, management techniques and use of modern marketing, which indirectly increases their value. It was only from 2007 on that GDP fluctuations were accompanied by quantitative changes in foreign capital in entities boosted with that foreign capital, which means that the impact on GDP of entities backed by foreign capital was insignificant up through 2007, and it was only after 2007 that a certain convergence may be observed between the two types of economic activities.

Similarly, the relatively stable dynamics of GDP were accompanied by considerable fluctuations in the investment expenditures of entities with 
foreign capital. Here it is also difficult to observe any connection between the two categories; thus, the impact of investment expenditure by entities with foreign capital on GDP was insignificant. Clear convergence may be observed, however, between the quantitative changes in the number of employees in entities with foreign capital and the dynamics of changes in GDP. It is easily observed that the fluctuations in GDP were also accompanied by almost identical fluctuations in employment. Thus, a conclusion may be drawn that both categories under analysis interacted.

Further evidence of positive foreign investment impacting the labour market is that while the employment level in a province increased insignificantly in the period in question, it increased by more than $100 \%$ in entities with foreign capital. Additionally, the share of people employed in companies with foreign capital also doubled as compared with the total number of employees in that area. It was also confirmed by observed changes where certain previously discussed categorized convergencies may be noticed.

Another, equally important effect of foreign investments on regional development is an increase in all investments, which is a definitely positive phenomenon taking into account the low internal accumulated capital, caused (inter alia) by a low level of national savings. This thesis is confirmed by the fact that while the total investment expenditure incurred by enterprises increased insignificantly, the investment expenditure incurred by foreign investors increased by more than $100 \%$. In view of the above, one may conclude that the investment expenditure incurred by entities with foreign capital became a more and more significant factor in regional development, which is additionally confirmed by the convergence of changes in the category's dynamics, despite a certain irregularity.

To sum up, the research proves that foreign investments do affect the economic development of Lower Silesia, but it is impossible to evaluate unequivocally whether or not the impact is as significant as local authorities would expect it to be. The impact of foreign investments on the labour market is easily observed, but it is difficult to present the direct impact of the investments in question on a region's GDP, despite an increasing investment level.

\section{Bibliography}

Cieślik, A. (2005) Geografia inwestycji zagranicznych. Przyczyny i skutki lokalizacji spótek z udziałem kapitału zagranicznego w Polsce, Warsaw: Ed. Uniwersytet Warszawski;

Czerwińska, E. (2001) Rola Bezpośrednich Inwestycji Zagranicznych w Polsce, Warsaw: Kancelaria Sejmu Biuro Studiów i Ekspertyz - Wydział Analiz Ekonomicznych i Społecznych, Information 789;

Dobrodziej, E. (1999) Kapitał zagraniczny w Polsce, Bydgoszcz: Oficyna Wydawnicza Ośrodka Postępu Organizacyjnego Sp.z o.o.; 
Frąckowiak, W. (2001) Z badańnad rynkiem kapitałowym w Polsce, Poznań: Wydawnictwo Akademii Ekonomicznej w Poznaniu;

Ministerstwo Gospodarki database, [Online], Available: http://www.mg.gov.pl/Wspiera nie+przedsiebiorczosci/Wsparcie+finansowe+i+inwestycje/Specjalne+strefy+ekono miczne/Obszar+SSE [20.12.2012];

Urząd Marszałkowski Województwa Dolnośląskiego datebase, [Online], Available: http://www.umwd.dolnyslask.pl/gospodarka/inwestycje-zagraniczne/ najwiksiinwestorzy/ [12.10.2012];

Interpelacja marszałka Grzegorza Schetyny [13.04.2011];

Karaszewski, W. (2007) Bezpośrednie inwestycje zagraniczne w Polsce. Polska na tle świata, Torun: Ed. Naukowe Uniwersytetu Mikołaja Kopernika;

Nowicki, M. (ed.) (2011) Atrakcyjność inwestycyjna województw i podregionów Polski, Instytut Badań nad Gospodarką Rynkową, Gdańsk: Fundacja Konrada Adenauera w Polsce;

Olesiński, Z. (ed.) (1998) Bezpośrednie inwestycje zagraniczne w Polsce, Warsaw: Polskie Wydawnictwo Ekonomiczne;

Popławski, M. (2012), Inwestycje zagraniczne w Polsce w latach 1989-2010, Wrocław: Ed. WSOWL in Wrocław;

Portal informacyjny Banku Danych Lokalnych: www.stat.gov.pl;

Rocznik PAIiIZ 2003 (2004), Warsaw: Polska Agencja Informacji i Inwestycji Zagranicznych;

Statistical Yearbooks of Lower Silesia 1999-2010 (2000-2011), Wrocław: Statistical Office;

Portal of the local data bank available at www.stat.gov.pl;

Sadowski, Z. (ed.) (1999), Kapitał zagraniczny w Polsce. Warunki działania, Warsaw: Dom Wydawniczy Bellona;

Studiów i Ekspertyz - Wydział Analiz Ekonomicznych i Społecznych, Information 789, June 2001;

Wieczorkiewicz, A. and Dąbrowska, K. (2002), Konsekwencje napływu kapitału z obszaru Unii Europejskiej do sektora bankowego w Polsce, „Ekonomia” Kwartalnik Wydziału Nauk Ekonomicznych UW, No. 6/2002 